\title{
BACK TO J. M. KEYNES \\ IN REGULATING INTERNATIONAL COMMODITY MARKETS: AN EXTENDED NOTE ON THE "TRANSPARENCY AGENDA"
}

\begin{abstract}
In this paper weak and strong forms of global governance of raw materials markets are compared. This is done by comparing the "transparency agenda» with the «structural reform agenda". John Maynard Keynes has worked for decades academically on commodity markets, on speculation and storage, on forward markets and buffer stocks etc., but he has also practised commercial trading activity on various commodity markets, and he has written and/or influenced the Post-World War Two ICU/ITO (International Clearing Union/International Trade Organization) agendas which are containing detailed provisions for establishing a world order on commodity markets. He was very much interested in the

(C) Karl Wohlmuth, 2018.

Wohlmuth Karl, University of Bremen, Germany.

A short Note was written 2012 in the context of a Radio Bremen discussion organized by Transparency International about transparency of payments by resource extraction companies to governments of resource-rich countries and other instruments for avoiding corruption and non-developmental use of resource revenues. This is an extended version, covering mainly the "Transparency Agenda» but shortly also the "Structural Reform Agenda». A following paper will consider the «Structural Reform Agenda» in greater depth.
\end{abstract}


relation between price volatility of raw materials and its impacts on global macroeconomics, but he was also convinced that appropriate regulations of commodity markets and sectors impact positively on peace and development. He was convinced that strong global governance must be based on simple, stable, effective, consensual and binding rules. Now the "transparency agenda" with regard of raw materials is so much debated but it is a rather weak form of global governance, while the "structural reform agenda" represents a rather strong form of global governance of the resources sectors. The "transparency agenda" is discussed in great detail in this paper while the "structural reform agenda" is considered in the Conclusions and Outlook section but needs further elaboration in a follow-up paper.

\section{Key words:}

Global governance, transparency agenda, structural reform agenda.

JEL: E58, E59, F02.

\section{Introduction: The New Interest in Regulating International Commodity Markets}

There is now increasing attention given to transparency of international commodity markets. Voluntary initiatives like EITI (Extractive Industries Transparency Initiative) and PWYP (Publish What You Pay) have a role to play although these initiatives are limited in coverage and effectiveness. New legal initiatives now play an increasing role, especially in the USA and in the EU, so as to increase the transparency of all types of payments by large and transnational raw materials-producing corporations to governments in developing countries, especially of countries with weak institutional contexts. In the USA the legal initiative is working along the Dodd-Frank Act of financial sector reforms and in the European Union it is working along the proposed transparency and accounting orders. 
However, the particular features, problems and complexities of international raw materials markets (with elements such as market cycles, market failures, market power, and market restrictions) cannot be addressed by these voluntary initiatives and the mentioned legal moves. Also, the complete lack of regulation of the international raw materials markets is a fundamental problem, for developing countries (suffering, for example, from resource curse and from export restrictions) and for developed countries (suffering, for example, from irregular and insecure supplies and from various forms of decisions taken under conditions of corruption). Both country groups suffer from macroeconomic management problems because of sharp price downswings and upswings of raw materials and oil.

The famous economist $\mathrm{J}$. M. Keynes has more than 65 years ago proposed a regulation of international commodity markets in the context of an International Clearing Union (ICU) and an International Trade Organization (ITO). Although both projects never materialized, there was some impact on the postworld war 2 economic order. The proposals to regulate commodity markets in the context of an international systemic approach have increasing relevance again now. The situation since 2007/08 with sharp food and raw materials price increases and the event of the 2008/09 global financial crisis have changed the picture. Although there is no chance to revitalize such ideas as an ICU or the ITO in the current world economy context, even in the context of the Bretton Woods organizations IMF and World Bank and the WTO and GATT rulings some meaningful programmes, provisions and waivers can be incorporated into the workings of these institutions so as to regulate some crucial aspects of the international commodity markets.

So many issues are now related to global commodity markets and connected with the main actors involved. The developed, the developing countries and the global economy are affected negatively and so there is potentially a common interest to work on a global commodity control mechanism.

Developed countries are affected in their macroeconomic management and in the management of their raw materials supply by sharp price level changes and price swings, by export restrictions of producer countries, and by a fundamental lack of transparency with regard of access to the natural resources in other countries, especially those of developing countries. There is at present no global system of rules in force to organize the global access to natural resources for small and large consumer countries and their firms - by defining and enforcing rules for the allocation of rights to explore and to produce, and also trading rules for raw materials and some processed materials are missing in many areas. As well rules for protecting the environment and the workers in producing countries are lacking so that the system is open to discriminatory production and trade conditions. The system is therefore very much affected by corruption and lack of accountability. Bilateral contracts between governments about the access to raw materials prevail more and more, so that latecomers in this 
process may have disadvantages. The market power of transnational and large corporations in the field of raw materials increases and determines the access to resources, so that home countries of such companies may enjoy advantages. Developed countries design their raw materials strategies, and such strategies may lead to conflicts between developed countries, such as between USA, Japan and EU, and even between countries within the EU. Such strategies may also lead to conflicts with developing countries and with transnational raw materials corporations.

Developing countries also suffer from severe macro-management problems due to raw materials price changes and swings and from the inability to control their resource sectors. Price level changes and price swings with regard of their resources affect the government revenues and the exchange rates, and because of management problems the non-resource sectors (especially agriculture and manufacturing) are discriminated and non-resource revenue loose in importance (Dutch Disease effects). Many countries also do not manage properly their resource stabilization and equity funds. All types of natural resources (land, oil and gas, minerals, forests, fishing grounds) in developing countries are increasingly affected by the international competition for scarce resources. The weaker the institutions in a country, the greater are the problems to avoid corruption and to ensure accountability. The weaker the institutions of a resource-rich country are, the greater is the risk that raw materials production is connected with conflict and violence, even with civil war and cross-border violence and military conflict. Also developing countries are affected by export restrictions and by the lack of investment rules and trading rules with regard of raw materials. Developing countries are affected by the market power (based on technology and knowledge, subsidiaries and networks, acquisitions and finance) of transnational and large resource extraction companies, as their own expertise and negotiation power is often weak (whatever the modalities of resource taxation contracts, service payment contracts and production-sharing contracts are). These countries also suffer from unequal economic power what leads to certain discriminatory trade and investment rules, and in this context they also suffer from a lack of support for processing activities. Also there is no accepted minimum level of transparency on social, safety and environmental standards, so that countries with weak institutions are not able to negotiate successfully on such issues.

For the global economy, global macro-management is affected by the commodity price cycles and price swings. As there is no mechanism in place to use countercyclical instruments at the global level (as proposed by J. M. Keynes in the ICU proposal and in his commodity control visions (based on international buffer stocks), only national strategies (if they are working) can be better coordinated, such as resource stabilization funds, commodity stocks, trading of national reserves, financial instruments based on commodities, and other measures. Regrettably, national stabilization and equity funds and sovereign wealth funds based on commodity revenues are not transparent in their investment strategies; 
the market power of such funds is often huge and it cannot be controlled by international actors. Trade rules are not ready to cope with export restrictions of food products and rare metals. Lack of transparency over reserves, resources, exploration and production as well as exports and imports of raw materials creates uncertainty about future supplies and - in relation to projected demand increases - spills over to the financial markets dealing with financial contracts related to raw materials. Uncertainty is also accelerated because of manifold interventions from governments (subsidies, duties, taxes, prohibitions, and quotas), leading to widespread market distortions. The global economy and the working of its institutions, like WTO, IMF and World Bank, are affected by these market distortions (huge subsidies for agriculture and minerals production), but also by long-term and shorter-term market cycles (with varying price swings at various price levels), by market failure (as there are various asymmetries in information between producers and users and between all types of contracting partners), by a hierarchy of market power (of a small group of huge transnational corporations and large national private and public companies which are specializing in all types of raw materials-related exploration, production, marketing, processing and servicing), and by a serious lack of regulation with regard of raw materials markets (as national laws and policies are not coordinated and as no international organization is dealing comprehensively with all the issues). As the UNCTAD Integrated Programme of Commodities has collapsed and as no further global initiative was launched (beside of minor initiatives from the side of UNEP, IMF, WTO, UNCTAD and others), the issue of commodity control is not touched systematically at the global level.

In this paper these issues are addressed by considering the difference between strong global governance as proposed by John Maynard Keynes and weaker forms of global governance as practised since years, like transparency initiatives, international standards, stakeholder forums, provisions in international agreements, international consultation forums, etc. This is done in the form of Guidelines for Action so as to highlight ten major issues of relevance in the current debate. These ten issues demonstrate why «moving back to Keynes» and turning to strong forms of global governance is important for regulating international commodity markets today. Five issues cover the "Transparency Agenda" and five issues relate to the "Structural Reform Agenda». While the Transparency Agenda is considered in great detail in this paper, the Structural Reform Agenda will only be touched in the final section of this paper, but it will get attention in a following paper. 


\section{John Maynard Keynes and the Need for Strong Global Governance of the International Commodity Markets}

The theory of speculation put forward by J. M. Keynes was developed in parallel with his practical activities as a trader and speculator in his asset company. His commercial and academic interest in many important commodity markets and his practical activities over a long period in these markets gave him enormous background knowledge how these markets really work and what the consequences of price volatilities, market irregularities and access interruptions are. His theory of speculation - assuming that the individual speculator undertakes an activity of risk-bearing which entitles him to earn a risk premium - was later extended by incorporating the institutional context and the institutional failures of these markets. It can be seen that the practical activity as a trader and speculator led him to new theoretical insights, also in favour of a regulation of commodity markets (see the detailed review of these issues in the essay by Marcuzzo, in: Marcuzzo, Ed., 2012). Because of the role of fluctuations of prices on commodity markets for effective demand in relation to boom and depression periods he saw an important field of public action. Case studies for cotton, wheat and tin show the wide practical interest of Keynes in commodity markets. The case of cotton reveals that the fundamentals of supply and demand are not the only factors to be accountable for price instabilities. All types of rumours, estimates, forecasts and factors mentioned somewhere about using land for cotton and many other news about facts and impressions about future developments had impact on prices in spot and futures markets (see Cristiano/Naldi, in: Marcuzzo, Ed., 2012). Of particular interest is the investment behaviour of Keynes on the cotton market. His asymmetric investment behaviour on the cotton markets (staying long with price increases and not necessarily short with price decreases) has to do with expectations about market developments of cotton as an annual crop. Different is the situation at metal markets. Speculation at the tin market showed Keynes the limits of commodity exchanges such as the LME (London Metal Exchange), with limited sources of supply, few sellers and buyers, imperfect information and attempts at manipulating prices). He became personally aware of the imperfect market conditions which are prevailing on such markets (see Cavalli/Cristiano, in: Marcuzzo, Ed., 2012). The experiences on the tin market influenced Keynes in his theory of business cycles, when linking effective demand and price volatility of commodity markets. However, he also saw the necessity to look at the whole value chain from mining to intermediate activities, like smelting, and then to the final users of tin. The intermediate level of tin smelters and their decisions about inventories brought Keynes to the view that tin mining (the first stage of the value chain) and (final) tin consumption are not the only de- 
terminants of price volatility. Inventories play a role and so the investment decisions for investments into stocks of the intermediate producers. Fundamentals of the market play a limited role. Prices are not always and not primarily indicators of relative scarcity of tin but are also the result of unpredictable decisions of smelters on inventories. The activity of Keynes on the wheat market brought him to the insight that institutional characteristics of markets (commodity exchanges Winnipeg and Chicago versus Liverpool) play a great role, as the Liverpool market got supply from all over the world, from the whole Commonwealth area and the colonies (like India and Australia), while the North American commodity exchanges had to rely basically on national supplies (see Foresti/Sanfilippo, in: Marcuzzo, Ed., 2012). Although an annual crop such as cotton, the market is different because of the spectrum of sources and trading areas. This brought him to the view that all the commodity markets and all the commodity exchanges are to be considered as special cases so that speculation at markets and the efficacy of regulation of markets are determined by the specific institutional environment. No other economist has done so much practical activity on commodity markets while reflecting over decades on these issues so broadly and deeply in his theories and policy recommendations.

However, Keynes was also much influenced by the discussion among leading economists (Hicks, Kaldor, Graham, Working, etc.) about the behaviour of prices and price differences on spot and futures markets. The basis issue is the interpretation of the expectations of individual speculators and what this means for the role of speculation on these markets - if their activity is stabilizing the commodity markets or not. The discussion brought out the need to move to heterogeneous expectations, with the implication that speculators trade also among themselves and not only with hedgers. The role of fundamentals (the productive role of speculation in relation to hedging) was thereby diminished in determining price differences, and also arbitrageurs came in as a third category of actors on such markets (see Cristiano and Paesani, in: Marcuzzo, Ed., 2012). Keynes analysed in detail the role of speculation on spot markets and on forward markets, showing for spot markets that for various reasons, like political uncertainties, weakened financial positions, and the role of expectations, the speculative holding of stocks is not counter-cyclical and so it is potentially destabilizing further the prices on commodity markets. Also with regard of the role of forward markets for the stabilization of commodity prices on spot markets he comes to a negative evaluation. He shows that in both situations - with and without liquid stocks - forward markets do not prevent wide fluctuations of spot prices (see Fantacci, in: Marcuzzo, Ed., 2012). All this led to the further development of the theory of storage. As neither speculation on spot markets nor on forward markets is stabilizing, the role of storage (private and public) has to be investigated. The theory of storage was developed further, by looking at the "convenience yields" of holding stocks for the producers/users of raw materials and at the "carrying costs" of those holding stocks. The theory of storage (developed further by $\mathrm{H}$. Working) moved the discussion away from expectations about price develop- 
ments and risk perceptions to yields and costs of storage (see Cristiano/Paesani, in: Marcuzzo, Ed., 2012). As determinants of commodity prices were seen by non-Keynesians like $\mathrm{H}$. Working convenience yields, carrying costs and efficient markets and not any more risk perception and heterogeneous expectations. However, tests contrasting these two explanations for price developments on raw materials markets (tin and cotton) show that both theoretical constructs have their merits. The new financial instruments used at raw materials markets and financial risk factors explain the price developments of cotton, while the developments of prices at tin markets seem to strengthen the theory of storage. The much higher speed of information dissemination (about determining factors and as well rumours about facts and developments on these markets) is a new phenomenon for both markets and leads to new market structures and market developments (see Cifarelli/Paesani, in: Marcuzzo, Ed., 2012). While the difference of convenience yields associated with stocks and the carrying costs for these stocks mirrors the difference between spot and future prices, the convenience yield depends on the level of stocks, implying also that carrying costs net of high convenience yields (associated with small stocks) are low. However, the smaller stocks are also affecting the volatility of prices, as the elasticity of supply decreases so that prices become more volatile with declining stocks (see Cifarelli/Paesani, in: Marcuzzo, Ed., 2012). It comes out that new developments (the financialization of commodity markets and the speedier diffusion of information) change the working of the raw materials markets and may lead to divergent developments of specific markets. Keynes was very interested in the dynamics of stocks, and so he may be accredited also with important aspects of the theory of price volatility as associated with the volume of stocks held as buffers. Mainly he was interested in the causes of the lack of private storage of surplus stocks, and what could be done to provide incentives for holding higher volumes of stocks.

Based on the view that raw materials markets are inherently unstable (because of the inability of the market to carry surplus stocks and because of the inability of the producers to restrict production quickly) and that speculation is not working so as to reduce these wide fluctuations, Keynes had suggested bufferstock schemes as public storage schemes, and his proposal for a new world currency mechanism (the ICU) foresaw means to finance such public buffer-stocks and so to act counter-cyclically on world business cycles (see Fantacci, in: Marcuzzo, Ed., 2012, for a review of the buffer-stock schemes proposed by Keynes; and see Ussher 2012 for a comparison of the buffer stock proposals by Keynes, Graham and Kaldor). All these background analyses by Keynes for the Commodity Control plan are useful reading as he saw it as a means to stabilize peace in the world. A public organization, an international one, should intervene to overcome the dilemma of high carrying costs of private stockholders (and in view of privately often unidentifiable and not easily measurable convenience yields). An international agency would be required to have impact on global macroeconomics, so as to make the international buffer stocks work as a means of countercyclical global economic policy. Such stocks would reduce the volatility of prices 
and would support global macroeconomic management in producer and in consumer countries (see Fantacci, in: Marcuzzo, Ed., 2012). Related to our times, financial instruments to reduce price volatilities would lose in importance, but the effectiveness of such instruments in this regard is anyway quite limited (if not counterproductive). Keynes came to the conclusion that stable economic systems require the existence of functioning competitive markets but in the case of raw materials markets the private incentives are not strong enough for sufficient storage. However, the public managers of such stocks have a great role to play (see Rosselli, in: Marcuzzo, Ed., 2012). This role as a public speculator among many private speculators, as a public manager speculating in the general interest, is a quite peculiar one. This public (international) manager must act as a «speculator of last resort» having enough freedom and financial backing to act without being committed to any pre-defined rule than to stabilize the raw materials markets (what is a clear difference to the public manager in the buffer stock plans presented by Keynes). All this reasoning is the base of the world economic order as proposed by Keynes for the period post-world war 2. The characteristics outlined are such as of strict and strong global economic governance in contrast to all the proposals since concerning regulation of raw materials markets (see next section), which all are based on weak forms of global economic governance.

Keynes influenced the post-world war 2 economic order more than any other economist (see George 2007). His proposals - going back to 1942 - for a world central bank, the International Clearing Union (ICU) and an international trade institution, the International Trade Organisation (ITO) are still of interest in our times, because of the huge imbalances in international trade and the related debt problems, the severe commodity market problems since 2007/2008 with impact on food security and access to raw materials, and the difficulties to update the provisions of the WTO in the Doha Round which started already in 2001. According to Susan George, Keynes did all the work for us 60 years ago (George 2007, p. 4), as his plan for an ICU and an ITO provided for orderly adjustment of surplus countries and for the development of deficit countries. The close relationship and interaction between ICU and ITO would have provided a much more coherent framework for global economic management than what we know from World Bank, IMF and WTO. More than this, there would be a pressure to import from developing countries allowing them to add value to primary commodities. The Reserve Fund of ICU and the provisions of the ITO would support this process in the daily working of these institutions. ICU and ITO were seen as complementary international organizations, and as part of a strong global governance mechanism (see on the versions of the Keynes Plan for an ICU the edition by Horsefield, Ed. 1969 for the International Monetary Fund, pp. 3ff, and the documents of the Final Act of the United Nations Conference On Trade And Employment with the Havana Charter for an ITO in UNCTE/United Nations Conference On Trade And Employment 1948). The international trade system should work smoothly, and the ITO should be supported by the ICU and the world currency for trade, the bancor. The ITO had some leading role, based on objectives such 
as full employment, development by protecting local agriculture and fisheries and by processing and manufacturing through structural transformation, social protection and labour standards, control of commodity markets, technology transfer, avoiding restrictive business practices, and stimulating and controlling foreign investment. The idea was to create international organizations which have clearly defined objectives, simple rules, comprehensive approaches, and effective working procedures. The ITO did clearly set the objectives and full employment played a crucial role. Commodity markets as they worked were seen as a risk to full employment policies, because of the reaction of fiscal and monetary policies in developed and developing countries to price volatility and price swings. Social and labour standards make sense in an international trade agreement if all nations and members are committed to full employment policies. Also the other objectives were interrelated and part of a system how the global economy should work. The ICU was supporting this process by its «automatic» reduction and elimination of current account surpluses and deficits. The Reserve Fund was financed also by this mechanism and should be used for international buffer stocks to reduce price volatilities. The rules were seen as simple, transparent and implementable. The overdraft facilities which were allowed in the ICU to all member countries were such a simple mechanism. Also the ITO system was simple in its working by using consultations and a dispute settlement mechanism. Comprehensive approaches should focus on all the relevant issues of the time. Effective working procedures should avoid high transaction costs.

Looking at the phase of global development at the time of the negotiations for a post-world war 2 economic order, it was in the period after the first wave of globalization (1860-1914) and prior to the period of the second wave of globalization (1950-1980) when such plans were discussed. The inter-war period was a break in the globalization process. Keynes was academically working on the severe institutional weaknesses of the first wave of globalization (Skidelski 2005, p. 18), based on the international gold standard and its adjustment mechanism, and he wanted to use the insights for designing an economic order for the coming wave of globalization beyond the revived interwar-period gold standard. As a market pessimist Keynes saw the complexity of rules, institutions and policies to maintain the stability of the global economy (Skidelski 2005), but he was convinced that the institutions have to be based on simple and coherent rules. The simultaneous pressure on creditor and debtor countries to clear their overdraft accounts (despite of being more a creditor adjustment system than a debtor adjustment system) was such a simple and clear rule. Creditor countries had the policy option to use their credit balances in various ways, but at the end of the year credit balances exceeding quotes were to be confiscated and transferred to a Reserve Fund (Skidelski 2005, p. 20). Related to the provisions of the ICU and its Reserve Fund was the Keynes Buffer Stock Plan intending to avoid fluctuations of commodity prices (as believed to be causing or amplifying business cycles) and to stabilise the incomes of the primary producers so that they can plan for imports and development (Skidelski 2005, p. 23). So the world economy 
needed a global macro-manager, also to vary contra-cyclically the supply of bancor, and a buffer stock manager so as to intervene in commodity market control activities. The ICU would finance buffer stocks and so would create a countercyclical instrument for an international incomes policy so as to smooth global business cycles (Ussher 2012). The ITO with all its provisions, especially the full employment obligation, the social and labour standards provisions, the provisions on primary commodities, foreign investment and restrictive business practices, fitted well into this scheme of contra-cyclical demand management by giving the countries enough policy space to act responsibly, but under the umbrella of a negotiated framework of economic cooperation (Drache 2000). The ITO provided for the policy space in an agreed international frame of mutual commitments, while the ICU provided the mechanism to balance the interests of surplus and deficit countries, of primary and manufactures exporters, of Northern and Southern economies, of central and peripheral countries in the world economy.

More than this, the ITO/ICU system was based on the idea of a true system in the sense of a negotiated and agreed upon global treaty of mutual commitments based on the principles of symmetry in adjustments and policy space for macro-management. This was much more than the Bretton Woods System and definitely also more than the Washington Consensus, the Augmented Washington Consensus and the periods of the Bretton Woods 2/Asian Dollar Standard system (Carabelli/Cedrini 2012). In fact, Keynes has presented a fully integrated programme of commodities (later named so by UNCTAD for a rather limited venture, because it was not related to global governance mechanisms (including the relevant international organizations) and because it was not comprehensive enough to provide for a system of linking reforms of the international monetary and finance system with reform plans for the commodity markets and with reforms concerning the broader trade, development and employment agenda. 


\section{Guidelines for Action: \\ From Weak to Strong Global Governance of International Commodity Markets through the «Transparency Agenda»?}

Ten issues are of relevance in the currently prevailing weak government regimes, and it has to be questioned to what extent reforms are possible towards strong global governance; in this paper five issues are considered in detail (the "Transparency Agenda»), and five further issues are mentioned in the final section only shortly (the «Structural Reform Agenda») ${ }^{1}$ :

\section{Issue 1: \\ Making Transparency Initiatives more Effective}

The idea is to control money flows from corporations involved in the exploration and extraction of raw materials to governments and all types of government authorities. Transparency Initiatives are now considered as most important approaches to fight corruption, assuming that corruption is preventing inclusive and sustainable development. There is a long history with such approaches, such as the Extractive Industries Transparency Initiative (EITI) and the Publish What You Pay (PWYP) initiative. According to the EITI model, resource revenue payments should become disclosed by using a voluntary and a multi-stakeholder approach, involving corporations, governments, parliamentarians and the broader civil society ${ }^{2}$. Payments by petroleum and mining companies to governments should be disclosed and verified in a specific process (see ADB/IACC 2010). Although there is an international focus, the reach is not broad enough, not covering forestry, fisheries, land, water and power; only extractive industries are covered. According to recent information, only few countries are fully compliant with the EITI requirements (ADB/IACC 201, p. 6). PWYP pushes for mandatory disclosure and obviously it does so with some success (although the global financial crisis of 2008/09 has given a strong push to such initiatives). However, such mandatory processes have only a regional focus, impacting on corporations listed at US stock exchanges (with the provision 1504 of the Dodd-Frank Act of

\footnotetext{
${ }^{1}$ Issues 6 to 10 (the «Structural Reform Agenda») will be discussed in a further paper by the author.

${ }^{2}$ See the EITI website on details about country members, working procedures, the listing and delisting of countries, etc.: www.eiti.org.
} 
July 2010), at the Hong Kong stock exchange (agreed on similar lines in 2010), and impacting on large companies and companies listed at EU stock exchanges (see ONE/Transparency International/Misereor/Brot für die Welt 2013 on the EU compromise agreement of April 9, 2013). Although these are regional provisions, they nonetheless would cover most of the corporations in the mining and oil and gas sectors, but based on divergent definitions and criteria.

Transparency Initiatives of a mandatory character were put in place in the USA as part of the Dodd-Frank Wall Street Reform and Consumer Protection Act. The Cardin-Lugar Amendment (Dodd-Frank Act Provision 1504) requires as part of the stock listing requirements that the extractive industries disclose in annual reports the payments to the US and to foreign governments in countries where they operate. Eight of the ten largest mining companies and 29 of the 32 largest internationally active oil companies are covered (PWYP/Publish What You Pay, The Cardin-Lugar Amendment/Dodd-Frank 1504). This transparency initiative is limited to oil, gas and minerals, but covers exploration, extraction, processing, export and "other significant actions». The payments for each project and for each government have to be disclosed. All payments such as taxes, royalties, fees including license fees, production entitlements and bonuses are to be reported. The EU Transparency Initiative is constructed on similar lines but there are substantial differences as well. Also large companies (public and private), not only stock listed companies, have to reveal their payments to governments, but the payments for processing and trade are not included. However, timber is included as well beside of mining, oil and gas. All levels of government and all forms of payments for concessions and advantages are part of the initiative (see on the complex EU discussion Mildner/Wasserberg 2012). There were serious controversies between the European Commission, the European Parliament and the European Council about the scope of the transparency and accounting directives, delaying the whole process for three years. Obviously on April 9, 2013 an agreement was reached between these three institutions, but it will take up to 2 years more to transform the directives into national law of the 28 EU states. Other initiatives refer to broader aspects of resource sector transparency beyond the payments to governments. The Revenue Watch Index (produced by Transparency International and the Revenue Watch Institute) provides more comprehensive information on the national natural resource sectors, although relying strongly on national government reports. Also large and transnational companies in resource sectors are scored with regard of disclosure strategies, especially by Transparency International, while Oxfam scores the biggest food and beverage companies with regard of sustainability and social impacts. Concerning land, forests, fisheries, water and energy some few initiatives were starting, but the focus is largely on mining, oil and gas.

The Global Civil Society (GCS) initiatives are increasing in number, experience and depth in analysis and demands for changes. Publish What You Pay (PWYP), EITI, Global Witness, and ONE are only the mostly known of these global NGOs. They demand now on a broad scale the disclosure of contracts 
and proofs that the extractive activities lead to better development outcomes, especially in the case of oil, gas and mining contracts. Although these Transparency Initiatives are useful as a start towards more comprehensive transparency of resource sectors and transactions, and are gaining some efficacy with the move from voluntary to mandatory forms, it is not so clear what national and global actions will follow to all this reporting. When, by whom and how does all this lead to global action? The complex issue of illicit financial flows (IFF agenda) is discussed now broadly at OECD level (and DAC level) and in this context the Transparency Initiatives are of some relevance (see on the IFF agenda U4 Brief, September 2012:8). It is also more and more accepted that international cooperation is needed to tackle the issue of capital flight from developing countries receiving ODA (Official Development Assistance), especially from Africa (see AfDB et al. 2012 on this issue and UNECOSOC/ECA 2013). As payments to governments are only one source of transparency risk, the many other sources (abusive transfer pricing, tax evasion, trade mispricing, money laundering and bribery) also have to be considered. International organisations and conventions already play a role, like internationally agreed tax standards and comparative information (OECD Model Tax Convention, OECD's Centre for Tax Policy and Administration), the FATF (Financial Action Task Force) against money laundering, the UNCAC (United Nations Convention against Corruption), the OECD Convention on Combating Bribery of Foreign Public Officials in International Business Transactions, etc. But, a harmonization of all these Transparency, Accountability and Disclosure Initiatives towards a global approach is not in sight.

John Maynard Keynes would say that transparency is a good idea although it is very difficult to reach it at raw materials markets if there are no binding rules at international level. Just because of these difficulties and differences market to market and because of the enormous importance of raw materials markets for global macroeconomics, for trade and for development he would favour also today a quite strict global regulation of these markets, based on ITO and ICU instruments, such as a control of transnational corporations, of foreign investment and of business practices.

\section{Issue 2: \\ Broadening the Impact of International Standards}

Setting international standards became an important and accepted means to attack the prevalence of corruption in raw materials sectors and to increase transparency on these markets. EITI is an important tool for setting international standards although only payments to governments are concerned and as only few countries are fully compliant. However, EITI emphasizes and practices a 
multi-stakeholder approach and from this side additional advantages arise for the involvement and strengthening of the civil society (see issue 4 below).

Other international standards mentioned are the UN Convention Against Corruption, signed in 2003 coming into force in December 2005 (see Argandona 2006). However, although there are good intentions, the Convention lacks a mechanism to support implementation and enforcement of the rules of the Convention. Although it is directed to public sectors/public officials and private business/corporations, it is a multi-stakeholder activity involving also global civil society representatives. It is an instrument to combine prevention and criminalization, and it focuses on international cooperation and technical assistance. There is a provision for a mechanism to return of proceeds of corruption to the legal owner, but all these rules lack enforcement measures. If implemented and enforced it could have some impact on actors in the raw materials markets, especially the governments and the corporations. Although there is some monitoring and reporting all this effort is in regard of outcomes weaker than the work of similar initiatives (by OECD, Council of Europe, etc.). Asset Recovery is an important principle in the Convention (see Argandona 2006), and for many producing countries especially in Africa this provision has high relevance in view of the extent of capital flight being related to raw materials exploration, production, processing, and marketing. Important for effective measures for «asset recovery» is the role of international cooperation, but exactly in this regard the Convention is weak. There is no mechanism to punish states who do not deliver according to the Convention rules. The civil society has a role to play, and can use the Convention as the base for their actions.

The Equator Principles for financial institutions are a risk management framework adopted by financial institutions «for determining, assessing and managing environmental and social risk in projects and is primarily intended to provide a minimum standard for due diligence to support responsible risk decision-making". ${ }^{3}$ Because of the capital-intensive nature of many internationally financed raw material projects such Principles, if applied, may play a role in preventing social and environmental risks affecting local populations. However, there is no assessment if these Principles play such a role. It is stated that $78 \mathrm{fi}-$ nancial institutions in 38 countries support these Principles and that 70 per cent of international project finance debt in emerging markets is covered. Robust standards are mentioned - for the livelihood of indigenous people, for the labour standards, and for the consultation with locally affected people - and should be part of all the projects supported by members. A multi-stakeholder approach is also emphasized, by providing a platform for clients, industry bodies, and NGOs, and the work of the initiative should be extended also to other agencies, institutions and initiatives by informing them and urging them to take similar action (OECD Common Approaches, Carbon Principles, Climate Principles, etc.).

\footnotetext{
${ }^{3}$ See Web Access: Equator Principles: Web Access: http://www.equator-principles.com/ index.php/about-ep.
} 
The Generally Accepted Principles and Practices (GAPP) - the Santiago Principles (IWG 2008) - have also a great relevance for enhancing the transparency on raw materials markets, by increasing transparency on Sovereign Wealth Funds (SWFs). The International Working Group of Sovereign Wealth Funds (IWG) was established at a meeting of countries with SWFs on April 30-May 1, 2008, in Washington, D.C. The idea was also to relate the issue to the broader prospect of providing more transparency of international financial systems and institutions. Twenty-six IMF countries are members of the IWG. ${ }^{4}$ An International Forum of Sovereign Wealth Funds (IFSWF) was established by the International Working Group of Sovereign Wealth Funds (IWG), which met in Kuwait City on April 5-6, 2009 to present the "Kuwait Declaration» ${ }^{5}$. The Forum adopted the Kuwait Declaration and intends to follow up on the issues of supporting global governance of investment and finance as regards the SWFs. The stated 24 Santiago Principles are of relevance for the international raw material markets as most of these funds have their revenues based on oil, gas and mining and/or have the revenues invested in the fields of commodities in the broader sense (including land, water, energy, and forests). The Santiago Principles refer to public disclosure requirements and sound asset management but there is no mechanism available to enforce states and SWFs to work along these principles. The task to set governance standards for sovereign wealth funds, and especially so with regard of commodity markets, is a huge one and there are inherent limits to it (see Issue 6 for details).

The FAO Voluntary Guidelines on Responsible Governance of Tenure of Land, Fisheries and Forest in The Context of National Food Security (CFS/FAO 2012) is another example of setting international standards. It was endorsed by the Committee on World Food Security and is also conceived as a multistakeholder activity as it is relying on groups and institutions such as G20, Rio+ 20, UN General Assembly, and the Francophone Assembly of Parliamentarians for implementation. ${ }^{6}$ It is not at all clear what these standards have achieved so far and who will support their implementation in future.

The Natural Resource Charter (NRC 2010) is also of some relevance. It was developed in a consultative process - with strong involvement of resource sector experts in the field and of the civil society. The Charter is directed at and should assist policymakers and citizens in resource-rich (developing) countries. It is containing 12 principles/precepts on best practice/best management experience with regard of natural resources, and wisely at all levels of the value chain ${ }^{7}$.

\footnotetext{
${ }^{4}$ See the Web Access of IWG (International Working Group Of Sovereign Wealth Funds): http://www.iwg-swf.org/pubs/gapplist.htm.

${ }^{5}$ See the Web Access of the International Forum of Sovereign Wealth Funds (IFSWF): http://www.ifswf.org/

${ }^{6}$ See the web access on these Tenure Guidelines: http://www.fao.org/nr/tenure/voluntaryguidelines/en/

${ }^{7}$ See the Web Access on the Natural Resource Charter: www.naturalresourcecharter.org.
} 
Ten principles (precepts) are directed to core decisions which governments have to face, while only two are directed to other actors. All principles (precepts) are presented at three levels. Level 3 is the most concrete elaboration of the specific principles (precepts). The principles/precepts, if translated into resource politics, would create linkages between the resource sectors and the other sectors and would maximise social, environmental and economic development benefits. It is not clear what the Charter itself could do to lead to a better implementation of projects and to better government policies towards the resource sectors. If a country-by-country monitoring scheme is linked to these precepts, then the deviations from the principles could be identified and compared (ADB/IACC 2010, p. 7).

The International Bar Association's Model Mining Development Agreement (MMDA) Project intends to formulate a template agreement for negotiations between investors and governments which is based on best practice clauses derived from real agreements of the past. ${ }^{8}$ It is a valuable project and the MMDA Website ${ }^{9}$ presents the model agreement in various languages as a template for negotiations. There is lot of multi-stakeholder activity involved. The project started in 2009 and is well advanced and working as a «living project», so that adjustments in the light of new experiences can be included.

The International Council on Mining and Metals (ICMM) as a club of commodity companies and commodity associations is joining the institutions which are submitting proposals for international standards. The ten Sustainable Development Principles (SDPs) formulated by the ICMM are based on a Mining, Minerals and Sustainable Development Project of the institution and were benchmarked against important international standards like the Rio Declaration, the Global Reporting Initiative, the Global Compact, the OECD Guidelines on Multinational Enterprises, the World Bank Operational Guidelines, the OECD Convention on Combating Bribery, the ILO Conventions 98, 169, 176, the IMF Performance Standards, the Indigenous and Tribal Peoples Convention, and the Voluntary Principles on Security and Human Rights. ${ }^{10}$ ICMM, as an association based on 21 mining and metals companies and many other commodity associations, states that it is committed to economic, social and environmental progress (see more on the TNCs in Issue 6). However, the behaviour of individual transnational mining and metals companies may be quite different so that ICMM may also be seen as a lobby group interest in reputational measures. However, ICMM may be useful as integrating transnational corporations from the BRICS countries. Also the human rights and security arrangements in extractive industries may get a push by ICMM's support of the Voluntary Principles on Security and Human Rights.

\footnotetext{
${ }^{8}$ Web Access IBA Model Mining Development Agreement Project: http://www.ibanet.org/ Article/Detail.aspx?ArticleUid=41f1038e-dcbf-44fd-ad17-898b7aa04a1a.

${ }_{9}^{9}$ Web Access MMDA Project Website: http://www.mmdaproject.org/

${ }^{10}$ See the Web Access on ICMM Activities and the Principles: http://www.icmm.com/
} 
Such voluntary international standards are only of limited relevance because of the lack of binding rules. These standards are highly uneven and unenforceable in their impact on the behaviours of these industry actors (ADB/IACC 2010 , p. 7). In cases of a strong civil society network being supported by local expertise, such standards can help to control governmental dealings and activities. Strengthening juridical and legislative powers can then also be a positive outcome. Surveys on the evaluations of the impact of such Natural Resource Governance Initiatives (see Acosta 2010) reveal more about the nature of the transparency and accountability process than about the impact on development outcomes. Future work needs to give more weight to the development outcomes (about linkages between resource sectors and other sectors, the use of resource revenues, and the social, economic and environmental benefits from such projects). There is a great need for donors to coordinate on the issues internationally and at the local level (see Darby 2010 for the T/A Initiative). The Transparency and Accountability Initiative (T/A Initiative) is a donor collaborative institution and intends to help donors to improve transparency and accountability in various crucial areas of their work. Many recommendations are given, among them to hold a dialogue between donors and key emerging countries, to provide more information on natural resource concessions, to provide more transparency at subnational level, to strengthen EITI, and to develop new revenue transparency mechanisms.

Again, John Maynard Keynes would say that International Standards are a good idea but should be developed under the umbrella of an international organization so that binding rules follow. Nothing of this type is prevalent in all these initiatives, and the sheer number precludes oversight and broad acceptance.

\section{Issue 3: \\ Strengthening Legal and Governance Systems at National and Regional Level}

There are many initiatives to support the strengthening of legal and governance systems as a way to initiate a framework for extractive industries before the production in extractive industry sectors really starts. The best way to develop legal and governance systems for extractive industries is prior to the production of oil, gas and minerals, and prior to the signing of contracts for licenses with resource corporations, and prior to the first annual flows of revenues and profits. Laws and regulations are instrumental to lay the foundations for a use of the natural resources in the national interest and to the benefit of the people. Discretionary decision-making can be reduced by legal rules that exist, that are made known and that can be monitored and ultimately enforced. The role of institutional actors has to be positioned clearly in these laws and regulations, and all 
the oversight rights and commitments have to be specified. This refers to all the relevant public and private institutions. The overall statutory environment, the legal role of public petroleum companies and of the private exploration companies who are applying for licenses, and the legal status of the institutions which are ultimately granting concessions for the exploration of raw materials matter, despite of the constraints to transparency emanating from the side of the executive branch of the government and from the political leaders. It plays a role to what extent the resource sectors are controlled by the legislative branch or by the executive branch. Some technical assistance was provided for countries with established and emerging resource sectors; multilateral and bilateral donors as well as many advocacy groups were active in recent years. Important is however the translation of good laws and regulations into resource politics and development policy at national level and local sub-national level.

Examples of good laws and regulations for resource sectors and of good governance systems as instruments for supporting the enforcement of such laws and regulations play a role. It is necessary to learn from best practice. The Fiscal Stability Law of Mongolia was passed in 2010 on the expectation of rapidly increasing resource revenues (see ADB/IACC 2010, p. 5). The size of the annual budgets was limited by law so that Dutch Disease and Resource Curse effects can be avoided from the outset by clear fiscal rules. Fiscal policy has some limits set by law, and this Fiscal Stability Law also makes it more difficult to spend money in illegal ways. However, when off-budget accounts are held for resource revenues beside of budgetary resource revenue accounts such fiscal stability laws may not apply as planned for. The quality of the overall governance system is decisive on the value and the proper use of such laws. It is also mentioned that some countries (Angola, Brazil, Libya, and others) are moving towards open and competitive auctions for oil exploration licenses (see ADB/IACC 2010, p. 5). If properly applied, such auctions have definitely advantages compared to the «secret allocations" of licenses in the past. Again, the overall governance system is important for long-term successes. For Angola and Libya there may be doubts about the working of such new instruments, and also Brazil has to show that the system works without high level and large-scale corruption.

It is argued again and again that legal frameworks and the associated institutions should be put in place before resource-fuelled corruption can destroy the legal and institutional frameworks and the basis of transparency in the resource sectors (ADB/IACC 2010, p. 5). Chad is taken as an example to show that oil revenue flows already started while laws, regulations and institutions were not yet embedded strong enough to stem against corruption and misuse of oil funds. Ghana is now credited with some advantage in this respect, as the country had time for building such institutions prior to the offshore oil and gas production. Oil was discovered in 2007, and already in 2009 a Fundamental Petroleum Policy paper was ready in Ghana, covering the fundamental petroleum policy issues, 
covering the main legal, institutional, fiscal and policy issues ${ }^{11}$. All the issues of regulation from the pre.-licensing stage to the processing stage were included. Again, the quality of the overall governance system will decide about appropriateness of these resource sector regulations. So again, the overall governance system matters for the development outcomes and not only the petroleum sector governance system. Three laws and institutions for the oil sector governance matter in Ghana in this regard ${ }^{12}$ : First, the Petroleum Revenue Management Act of 2011 (Act 815); second, the Petroleum Commission Act 2011 (Act 821); and third, the Public Interest and Accountability Committee (PIAC). The Petroleum Revenue Management Act «has strong provisions for governance, oversight, transparency and accountability, including rigorous rules for reporting on oil fund assets, expenditures and investments. The most unique feature of Ghana's petroleum revenue management regime is found in the creation of the Public Interest and Accountability Committee (PIAC), a 13-member body comprising the Bar Association, TUC Ghana Journalists Association and others, to monitor government in its management of the revenues from oil». (Kufuor Speech 2013, see Note 13). Translation of laws and regulations into practice applied by governments depends on the overall governance system in the country. However, the evaluation of Ghana's resource sector policies in the context of the CPIA Index by the African Development Bank is so far (up to 2011) showing encouraging results. Ghana has also signed up to the Open Government Partnership and EITI (Kufuor Speech 2013, see Note 13). There is also a donor-funded project in Ghana which is called Natural Resources and Environmental Governance (NREG) with the task to look at the social and environmental consequences of timber, mining, and oil and gas exploration and related production activities. ${ }^{13}$ It has relevance for the forestry sector, the offshore gas and oil production and the mining activities in the country. The results are however mixed. Anyway, the case of Ghana is relevant for Uganda and other newcomers to the mining and oil and gas producers' community in Africa. Although the oil find in Uganda preceded the one in Ghana, and although the same international oil company works in both countries, Ghana was quicker in realising the oil production, and now it can advise the newcomers on important steps to control the resource sectors and to make the people benefit. All the experiences reveal that the civil society has to insist on a strong role for the parliament in resource sector policies and oversight

\footnotetext{
${ }^{11}$ Ministry of Energy, Ghana, Fundamental Petroleum Policy for Ghana, 16 pages, Web Access: http://www.energymin.gov.gh/wp-content/upLoads/Fundamental-Petroleum-Policyof-Ghana.pdf.

12 Former Ghanaian President Kufuor speaks on August 2, 2013 on oil governance at Makerere University; see Web Access of the Kufuor Speech: http://www.acme-ug.org/ news/item/489-former-ghanaian-president-kufuor-speaks-on-oil-governance-at-makerere. ${ }^{13}$ See the World Bank Website on the Ghana Natural Resources and Environmental Governance (NREG) support program: http://web.worldbank.org/WBSITE/EXTERNAL/ PROJECTS/0,,contentMDK:22701705 menuPK:64282137 pagePK:41367 piPK:279616 the SitePK:40941,00.html.
} 
and for a legal statute of oil boards and national oil corporations to be controlled by the parliament. The parliament, the civil society, and the EITI process can combine their forces towards enhanced transparency and accountability.

Other countries have failed to translate strong laws and regulations to practical work, as for example Cameroon (see ADB/IACC 2010, p. 5). Sudan and South Sudan are serious cases of government failure as they have neither strict regulations nor the political will to act accordingly (Wohlmuth 2012). Although parliaments and elected legislature play an increasing role in the oversight of the resource sectors, there are in many countries severe constraints, as a review for nine African countries also shows (see the detailed study by Bryan/Hofmann, Eds., 2007). Recommendations resulting from the report are given to legislative bodies and to individual members of the parliament, but also to international advocacy groups and to local civic activists and organizations. The Report makes it clear that all these actors (legislators, advocacy groups and civic society actors) can benefit from cooperation among each other and from international networking. EITI is all over the cases mentioned as a good instrument to involve the broader civil society and the legislature. However, when high level political elites continue with corrupt behavior then the danger is great that all these transparency and accountability initiatives are handicapped by threats, by specific favors to individuals, and by seeding mistrust (see Bryan/Hofmann, Eds., 2007). The role of the civil society is extremely important to follow up all the steps taken by government and by the oil, gas and mining companies as well as the actions taken by the many services companies acting on behalf of the governments and the oil, gas and mining companies.

John Maynard Keynes would definitely like the role of enlightened legal and governance systems for resource sectors at the national level, especially when the commodity sectors are coordinated and guided in the context of international organizations with binding rules, like the ITO and the ICU. As seen above, there are so many actors involved but no binding rule is in sight.

\section{Issue 4:}

\section{Propagating the Multi-Stakeholder Approach at National, Regional and Global levels}

The Multi-Stakeholder (MSH) approach has found a great interest in regard of solving commodity market problems. It is credited with some successes in improving governance in resource-rich countries and in reducing corruption in resource sectors. The Multi-Stakeholder Committees provide forums for discussion of issues, information exchanges, drafting appeals to politicians, governments and corporations, and formulating demands for changing procedures and 
regulations to oversee the raw materials. Also, these committees can help to create trust between actors which is often minimal because of bad experiences and disappointments. Because of high risks for corporations to invest in raw materials production in some countries (because of conflicts, political instability, lack of infrastructure, bureaucratic delays, etc.), especially in Africa, such committees may also be of interest to corporations which are interested to invest. Corruption is not the only problem which investors in such a high risk environment have to face. Many producer countries in Africa have unfavourable values/rankings for the "ease of doing business" and "governance» indexes, and also the CPIA (Country Performance and Institutional Assessment) Indexes of World Bank and African Development Bank are often poor.

Such committees can also help to inform and to increase transparency about criminal actions, like illicit payments; the financing of criminal entities and networks; human rights violations, such as forced labour and relocation of people for the purpose to clear land for extraction; inappropriate land use; and the violation of international sanctions. Also the illegal practices of local joint ventures linked to major transnationals are of concern in such committees, as it is dangerous to report about connections of such joint ventures to political groups, government circles and high level politicians. The reputation of companies may be at stake, and therefore such committees may help to prevent further damage (see Badal 2012). US Dodd-Frank Act provisions 1502 and 1504, together with other provisions by US law, will have some impact on the corporations and such committees may give early warning signals about reputational damages. Investing in high risk, high conflict and weak governance areas requests a systematic analysis of risks, and so such MSH committees can be useful (Badal 2012). However, civil society and other stakeholders have their own interests and these have to be considered by company representatives. It is quite often argued that EITI had more impact on improved interactions between civil society groups, government officials and representatives of corporations than on data disclosures and verification as such. Future dialogue can be enhanced by trust created in such committees.

Examples of success play a role. Timor-Este and Ghana provide examples of the usefulness of such multi-stakeholder committees. The Petroleum Fund Consultative Council in Timor-Este, in the context of the 2005 Petroleum Fund Act, provided such a forum. The Public Interest and Accountability Committee (PIAC) in Ghana is another example for an institutionalized $\mathrm{MSH}$ forum (ADB/IACC 2010, p. 8). Other sectors also come in with such MSH committees. Mentioned is quite often the UN Collaborative Initiative on Reducing Emissions from Deforestation and forest Degradation (REDD) in developing countries (see the website of the UN-REDD Programme). ${ }^{14}$ All relevant stakeholders are in-

\footnotetext{
${ }^{14}$ The UN-REDD initiative is an activity by FAO, UNDP and UNEP to reduce emissions; see the web access: http://www.un-redd.org/
} 
volved in this EITI-type process, especially also the indigenous people and the communities which are depending on forests. The Programme is now working in 47 countries and is functioning as a national and international multi-stakeholder process. The Electricity Governance Initiative, managed by the World Resources Institute (WRI) is also mentioned (see ADB/IACC 2010, p. 8) as a MSH initiative to formulate equitable and sustainable electricity policies, to increase transparency, and to provide for inclusiveness and accountability of electricity governance $^{15}$.

However, successes may vanish after some time, so that it is necessary to revitalize such MSH approaches continuously. The case of Nigeria shows the life cycle of EITI processes. In the period $2004-2006$ there was a strong EITI-type stakeholder and disclosure process, involving all major partners, but later the incentives for such a process diminished rapidly (see on the sources: ADB/IACC 2010 , pp. $8-9$ ). It is therefore necessary to uphold incentives and to secure the backing for such moves from the high level political leaders. In Nigeria, the incentive for the government was to get large-scale debt relief on HIPC-terms, so that such transparency measures were part of a package. International and national pressure is needed continuously to create and to maintain such favorable conditions for incentives and action. Such MSH approaches need strong supporters at international and regional levels. EITI is supported strongly by the World Bank Group and EITI preceded the World Bank Extractive Industries Review ${ }^{16}$ with its recommendations on disclosure of government revenues from extractive industries. This strong support thereby contributed in making the multi-stakeholder process a multi-level process (from national to regional and to international levels for MSH committees in extractive industries). The Kimberley Process (KP) on conflict diamonds is also a MSH process as it is a joint government, industry and civil society initiative; it is supplemented now by US legal provisions for certification along the value chain and also by UN sanctions (see Issue 5 for details). The Kimberley Process (KP), which is also defined as a joint government, industry and civil society initiative, is equipped with its Kimberley Process Certification Scheme (KPCS) ${ }^{17}$ and involves 49 members representing 75 countries, because of the EU counting as an individual member (Acosta 2010). Multi-stakeholder voluntary initiatives are also strong in forest sectors - the Forest Law Enforcement and Governance (FLWEG) process, the REDD process, and the Forest Stewardship Council (FSC) have to be mentioned, but all this activity raises the question why it is not possible to join forces by merging these initiatives to form a stronger one under the umbrella of an UN organization (see Acosta 2010). Therefore, a new generation of multi-stakeholder governance initiatives is

${ }^{15}$ See more on the Electricity Governance Initiative on the website of the World Resources Institute: http://www.wri.org/project/electricity-governance.

${ }^{16} \mathrm{See}$ on the World Bank's Extractive Industries Review the Website: http://web.worldbank.org/WBSITE/EXTERNAL/TOPICS/EXTOGMC/0,,contentMDK:20605 112 menuPK:592071 pagePK:148956 piPK:216618 theSitePK:336930,00.html.

${ }_{17} \mathrm{See}$ on the activities of the Kimberley Process the Website: http://www.kimberleyprocess.com/ 
needed to get stronger and more effective what requires also capacity building, identification of new fields and instruments of activity conceived around sustained need, selecting the right people, and learning from parallel MSH efforts. Also cooperation with other initiatives, like the Stolen Asset Recovery Initiative $(\mathrm{StAR})^{18}$ and the Public Expenditure and Financial Accountability (PEFA) program ${ }^{19}$, is needed to have more effective measures at hand (see Acosta 2010).

Also at regional level, for example at the level of African Regional Economic Communities (RECs), such MSH initiatives for the resource sectors are starting to work. A regional approach is requested in Africa to contribute to conflict prevention in the context of extractive industries (UNEGM/UN Expert Group Meeting 2006), and this process could led to deeper forms of cooperation on such issues than based on voluntary multi-stakeholder meetings; parallel to such a process a strengthening of the RECs could follow. The Africa Report on Institutional and Strategic Frameworks for Sustainable Development (UNECOSOC/ ECA 2011) requests a sub-regional and regional multi-stakeholder framework for improving sustainable development governance in Africa. ${ }^{20}$ This report shows the clear need to extend the multi-stakeholder approach to various levels of governance in Africa. The increasing number and size of «land grabs» in Africa requests a quick move to such region-wide and sub-region-wide MSH activities in order to avoid further damages in terms of sustainable development ${ }^{21}$. The problem is the more serious as even governments and large corporations which are close to their governments are among the top investors (Indian Government; ZTE International, China; Tata Power, India; Samling Group, Malaysia; Daewoo Logistics, South Korea; Sinar Mas Group, Indonesia; and Muting Hijau, Indonesia. In Africa, Ethiopia, DR of Congo, Zambia, Sudan and Madagascar are the preferred locations for the top investors, while Malaysian and Indonesian investors invest mainly in their own countries. African countries like DR of Congo, Ethiopia, Sudan, Madagascar, Zambia, Tanzania and Mozambique are among the countries where high investments take place (see Note 21 for the source). Still Africa waits for a regional and sub-regional approach of regulation and transparency. Also «water grabs» are of increasing relevance and impact, so that water gov-

18 The Stolen Asset Recovery Initiative (StAR) is a cooperation of World Bank and UNODC (United Nations Office on Drugs and Crime); it is also cooperating with the civil society and many other partners; see the Website: http://star.worldbank.org/star/

${ }_{19}$ The Public Expenditure and Financial Accountability (PEFA) program is a multi-donor partnership between seven donor organizations and financial organizations, but it is also including a PEFA Network with numerous interested stakeholders, and so it is also a MSH activity; see the Website: http://www.pefa.org/

20 The Africa Report Summary for Policy Makers highlights the most important issues of sustainable development governance; see the document: http://repository.uneca.org/ handle/10855/20583.

${ }^{21}$ See for the recent data (April 2012) on «land grabs» in Africa: http://www.theguardian.com/global-development/datablog/2012/apr/27/international-landdeals-who-investing-what. 
ernance initiatives matter ${ }^{22}$. Biofuels require over the whole production cycle large amounts of water, and land grabs also lead to high consumption of water for the production thereon. There are diverse institutions at international level with a MSH approach on water governance, like the Alternative World Water Forum $(A W W F)^{23}$, the Water Operators' Partnerships Initiative, and the UN Global Water Operators' Partnerships Alliance ${ }^{24}$ (see on all these MSH approaches/initiatives: TNI/Transnational Institute 2012). These institutions are also interested in critically investigating the huge dam building projects, such as the damming of the Congo River at Inga Falls ${ }^{25}$. Contrary to the philosophy of these international alliances which consider water as a common good/a public good and water governance as a public sector activity, the World Water Council ${ }^{26}$, the World Water Forum (WWF) and the Global Water Partnership ${ }^{27}$ look at water rather as a commodity/a private good (see TNI 2012, pp. 19-20). Huge networks on water, but with a quite different focus, are prevailing at global, regional and national level. Also a MSH initiative, involving a number of governments, the civil society and other stakeholders in the Nile Basin region, is the Nile Basin Initiative $(\mathrm{NBI})^{28}$. This initiative is so important and reminds the international community daily of all the potential and actual conflicts which could arise and indeed arise if a management of scarce water resources with entitlements across the borders

22 The Transnational Institute in Amsterdam, The Netherlands works on the issues of land and water grabs; see the website: http://www.tni.org/category/issues-workarea/agrarianjustice/water-grabbing- 0 .

${ }^{23}$ The Alternative World Water Forum (AWWF) is conceived as an alternative to the World Water Forum (WWF), which is organized by the World Water Council, considered by AWWF as a club in the interest of transnational corporations and the World Bank; see Web Access to the Alternative World Water Forum (AWWF), in French it is abbreviated as FAME: http://www.fame2012.org/en/

${ }^{24}$ GWOPA is supporting water operators' partnerships (WOPs) which are itself MSH initiatives; the Building The Water Operators Partnership Platform for Africa is such an activity supported by GWOPA; see the Website of GWOPA (Global Water Operators' Partnerships Alliance): http://gwopa.org/

${ }^{25}$ See the story on the Grand Inga project in the DR of Congo, considered as the world's largest and most expensive dam building hydropower project, and being a giant SouthSouth project involving South Africa and the DRC: http://www.fame2012.org/ en/2013/07/07/congo-largest-dam-project/

${ }^{26}$ The World Water Council is defined as a MSH platform to create awareness about the future of water around a network of competencies; it is organising the World Water Forum; see on the activities of the World Water Council their Website: http://www.worldwatercouncil.org/index.php?id=1.

27 The Global Water Partnership is working towards water security issues; it is also a networking and MSH initiative; see the Website at: http://www.gwp.org/

${ }^{28}$ The Nile Basin Initiative (NBI) was established in February 1999 and has 10 member countries sharing the Nile Basin waters, while Eritrea is an observer; it is a purpose to share the Nile Basin water resources for developmental benefits; see the Website: http://www.nilebasin.org/newsite/index.php?option=com_content\&view=frontpage\&ltemid= 1 \&lang=en. 
(across many borders) is not regulated and managed well. In its awareness creation function the NBI has also a huge networking role and has become a MSH platform. However, conflicts on Nile waters quotas of the upstream riparian states, including Ethiopia as the main provider of Nile waters, with Egypt and Sudan (the main users of Nile waters because of their old treaties) affect the working of the NBI. A Cooperative Framework Agreement (CFA) between now six upstream countries seeks to find a more equitable sharing of the Nile waters among the riparian states. Ongoing conflicts around dam building projects in the $\mathrm{NBI}$ countries could escalate to military conflicts.

At global level, the multi-stakeholder approach is requested for solving future resources problems and for formulating a new and concerted resources policy (the new Chatham House report on Resources Futures brings out policy recommendations involving a much stronger framework for action; see Chatham House 2012). The influential report recommends the formation of a new club of the most important consumers, importers, exporters and producers of resources in the world (excluding the smaller actors in contrast to what the draft for the ITO has envisaged). The Resources 30 (R30) group should fill governance gaps so that important elements of governance on global resources and scarcities could be established. Although an informal club, it could have weight as a MSH initiative which is supported by professional advice, by transnational corporations and the international trading community. It will be composed of political leaders, national and international public officials and other (private sector and civil society) stakeholders. This group of the «committed» could start with filling most urgent gaps in global governance of resources sector. Although working as an informal group of the "committed», it could tackle issues such as severe price increases, export restrictions, resource conflicts, etc. Price volatility at the sector level, export restrictions of certain resources, and severe global price increases and price falls could be influenced by joint action, and some mechanisms for potential action are mentioned in the report (Chatham House 2012). Devising guidelines on regional and global stocks, on the use of export restrictions, on the role of IEA and OPEC, on global and regional production and investment policies, and on ways to encourage transparency on state-owned enterprises and transnational corporations in the field of resources would be important tasks of the new club (see on the concrete proposals the Chatham House Report: Chatham House 2012). The R30 group could also involve IEA, WTO, World Bank, OPEC, commodity exchanges, commodity sector groups, leading transnational corporations, professional organizations, and international NGOs to effect at the global and regional levels a reduction of vulnerability to short-term price and supply shocks, a turn to a more inclusive and sustainable resources production with higher resilience at the level of nation-states, and a reconstruction of rule-based global and regional resource governance.

What would John Maynard Keynes say? He would say that this was already part of his ideas for an ITO Charter, but that such MSH initiatives could be 
a starting point for a rule-based global resources governance system. He would also say that international agreements with stable, simple, binding and effective rules are ultimately unavoidable in the resources sectors. As a realistic observer of international institutions and negotiations he would recommend to install from the start financial windows and regulatory mechanisms and to get a mandate for severe crisis situations (what partly is intended from the outset for the R30 group).

\section{Issue 5: \\ Broadening the Systems of Certification of Raw Materials along the Global Value Chains and Using UN Sanctions in Conflict Situations}

The certification, authentication and identification of the source of specific commodities (diamonds, gold, tungsten, tin, and tantalum), which are labelled as "conflict diamonds" and conflict minerals", along the whole value chain from artisanal mining to the end consumer, is increasingly considered as an important instrument to contribute to conflict prevention, by avoiding that the revenues are used for arming militias and terrorist groups. Transparency along the value chain is requested by the Kimberley Process (for diamonds) and by the Dodd-Frank Act provision 1502 (for minerals like tin, tantalum, tungsten, and gold). The DoddFrank provision 1502 is very demanding for the corporations listed at the US Stock exchanges; the Rules are complex but there are no further juridical doubts on them since the mid-2013 decision of the court so that the corporations have to cooperate fully ${ }^{29}$. The Rules request a user of potential «conflict minerals» (originating in the DR of Congo or adjoining countries) to submit a report stating what the user has done to identify the true source of the minerals along the whole value chain, and to give evidence about the source so that it is clear that the revenues are not contributing to conflict generation. The measures taken to proof due diligence must include an independent private sector audit of the report, and the report has to be conducted in accordance with standards established by the Comptroller General of the United States. The report has to state clearly that the products manufactured or contracted to be manufactured are not using «conflict minerals». Mining should go on in the DR of Congo so that the workers can earn an income, but the evidence has to state that the revenues are not channeled to unauthorized groups.

The supply chain has various stages from the small artisanal producer to the mine, then to the local exporter and to the smelter, then to the industrial pro-

${ }^{29}$ The SECURITIES AND EXCHANGE COMMISSION has released on August 22, 2012 Rules on conflict minerals, covering not less than 356 .pages; see the Website: http://www.sec.gov/rules/final/2012/34-67716.pdf 
ducer, the (electronic or another) industry using such minerals like tin, tantalum, tungsten, wolfram and gold, and finally to the end consumers. Companies are requested to give proof of the source by the use of internationally accepted standards of certification and identification. According to Global Witness the warning is clear: «There are four main minerals being mined by the population in eastern Congo: cassiterite (the ore for tin), coltan (the ore for a rare metal called tantalum), wolframite (tungsten ore), and gold. The illicit trade in these minerals provides rebel groups and units of the national army with tens of millions of dollars a year that they use to buy guns and shore up their rival campaigns ${ }^{30}$. There seems to be some progress towards "conflict-free» supply chains for tin and tantalum in the eastern DR of Congo. Again by citing Global Witness: «In October 2012, the Conflict-Free Tin initiative (CFTI), a closed-pipe system in which all players in the vertically-integrated supply chain are known, was launched in eastern DRC's South Kivu province. Major SEC-listed companies are participating in the project, including firms who were not previously buying minerals from the Great Lakes Region. Although in its early stages, the CFTI is an example of how, if properly implemented, responsible sourcing from conflict-affected areas in eastern DRC could become a reality". (See for Global Witness as the source: Note 31). It is reported that this initiative is still a pilot project, but the description of the project shows that there are developmental benefits from it in the region. ${ }^{31}$ $\mathrm{PACT}^{32}$ is the implementing agency for the certification programme iTSCi (ITRI Tin Supply Chain Initiative). ${ }^{33}$ Upstream companies are assisted to conform with the OECD Due Diligence Guidance (DDG) for Responsible Supply Chains of Minerals from Conflict-Affected and High-Risk Area (see OECD 2013) and with the recommendations of the UNSC (UN Security Council) to expand due diligence on criminal networks and armed groups and «to include violations of the asset freeze and travel ban on sanctioned individuals and entities». (See as the source Note 34). The OECD Due Diligence Guidance (OECD 2013) has five steps (establishing strong company management systems; identify and assess risks in the supply chain; design and implement a strategy to respond to identified risks; carry out independent third-party audit of smelter/refiner's due diligence practices; and report annually on supply chain due diligence) for tin, tantalum and tungsten, and similarly for gold. As there are many neighbouring countries of the DR of Congo (9 neighbouring countries) and as it is not easy to control all the shipments of minerals from this area, there may still be weaknesses in the system and losses for the government and for the local people. Corruption

\footnotetext{
${ }^{30}$ See the Website of Global Witness on Conflict Minerals: http://www.globalwitness.org/ campaigns/conflict/conflict-minerals.

${ }^{31}$ See on the Conflict-Free Tin initiative (CFTI) the Website: http://solutionsnetwork.org/site-cfti/results/

${ }^{32}$ It is the mission of PACT to support local communities; see the Website: http://pactworld.org/

${ }^{33}$ See on the certification programme iTSCi (ITRI Tin Supply Chain Initiative) the Website: https://www.itri.co.uk/index.php?option=com_zoo\&task=item\&item_id=2192\&ltemid=189.
} 
and smuggling affect the work of all certification institutions, especially in cases when governmental actors are involved. Changes in the world market for tantalum (used in high technology sectors like mobile phones) mean also that the DRC and few other African countries got an enormous importance since 2009 when the African share of the market shot up to over 50 per cent (see Lauster/Mildner/Wodni 2010). This has also to do with the very low wages of workers in such conflict areas as militias and armed groups put pressure on the workers and the traders. But the increasing involvement of such certification agencies may create awareness among all actors in the supply chain. As such certification/identification systems may be of great importance for other countries with conflicts too (like the Sudan with a lot of artisanal gold mining in Northern Sudan and with around 500,000 workers being employed under miserable working conditions, or the Central African Republic with regard of diamonds mined in artisanal production), the examples of the "conflict-free» initiatives in the eastern DR of Congo and adjoining countries and the examples of the Kimberley process countries may be of relevance for an extension of the system to other countries and regions. However, examples also show that such systems will fail - as in the case of "conflict diamonds" - if governments do not cooperate when using offbudget accounts for such revenues (then used for fighting the opposition as in Zimbabwe). ${ }^{34} \mathrm{~A}$ report by Global Witness analyses the international connections of business, intelligence services in Zimbabwe and mining of diamonds in the country (Global Witness June 2012). Also the case of Angola shows that the Kimberley Process (KP) needs adjustments as also state actors (as powerful generals in Angola) are active in the mining sector and are part of the problem of generating conflicts and violence in the mining industry by using force through security agencies they own. As generals are active in the diamond business as well as in the private security business the Kimberley Process needs to embrace also such (government/army/security) stakeholders and not only those from rebel groups (see Ebertz/Müller 2013). It is recommended to move to a wider definition of "conflict diamonds» what requests action at EU and UN levels to change the KP definitions and procedures. If such efforts fail the OECD Due Diligence Guidance for Responsible Supply Chains of Minerals from Conflict-Affected and HighRisk Areas (see OECD 2013) should be brought in as a substitute to complement the KP as the OECD has a wider definition of "conflict diamonds" (see Ebertz/Müller 2013, p. 14). Also chemical-mineralogical footprint solutions do not work if not all the relevant coltan/tantalum producer areas can be recorded; and the same problem is with other minerals (see Lauster/Mildner/Wodni 2010, p. 3). So, from the side of the law on transparency in manufacturing countries to the side of the local control in producing areas there are many issues open. The International Accounting Standards Board (IASB) is working on a similar provision as Dodd-Frank 1504 (on corruption), and all this could be extended to 1502 (on conflict minerals) and 1503 (on health violations). Global solutions with a high

${ }^{34}$ See on the problems of these "conflict diamonds» the Website of Global Witness: http://www.globalwitness.org/conflict-diamonds. 
level of enforceability are needed because of the many possibilities to circumvent regional and national initiatives (see also Lauster/Mildner/Wodni 2010, p. 4).

In order to get certification/identification/authentication of the source, various systems are available along the value chain. Such international standards could give evidence of social and ecological aspects, of working and safety conditions, they could give an identification/authentication of the true production location of the minerals, and they could inform about the further channels and uses of the minerals in the value chain, as well as about the legality and the transparency of the flows of minerals. There are various systems with different focus along the value chain (see the Chart of the Month, by DIHK/DERA October 2012). At the level of production of ores up to the level of the smelter in the value chain, four certification systems matter (CTC/Certified Trading Chains; AFP; ICGLR; and iTSCi). The CTC was developed for the Artisanal and Small-Scale Mining (ASM) sector, assuming that industrialized and Large Scale Mining (LSM) operations "commonly operate within acceptable corporate social and ecological responsibility (CSER) standards," (See BGR/Bundesanstalt für Geowissenschaften und Rohstoffe 2010). CTC is described as «a voluntary system of selfcommitment by the partners in the trading chain». (see: BGR 2010, p. 3). Integrity standards were derived on the basis of the OECD Guidelines for Multinational Enterprises (2000) and the OECD Risk Awareness Tool for Multinational Enterprises in Weak Governance Zones (2006), and some of the International Finance Corporation's Performance Standards and the Voluntary Principles on Security and Human Rights. Five standards matter (BGR 2010, p. 5): transparency of payments to the host government; no use of child labour and fair remuneration of workers, and fair working conditions, health and safety standards; security on production sites is guaranteed and and human rights are respected; communities are consulted and institutional development is supported; environmental conditions are considered). CTC - with activities in Rwanda and the DRC - is part of a regional mechanism (ICGLR/International Conference on the Great Lakes Region). ICGLR ${ }^{35}$ has launched a regional certificate on the origin of minerals in DRC (see the ICGLR News Bulletin for July 2013). The AFP (Analytical Fingerprint) method is a forensic tool (see BGR 2013) to identify the source of minerals, and it is also of relevance for CGLR's Regional Initiative against the Illegal Exploitation of Natural Resources (RINR). CFS (EICC/GeSI) is another initiative. CFS (Conflict-Free-Smelter) is supported by EICC (Electronic Industry Citizenship Coalition) and GeSI (Global e - Sustainability Initiative), another association of the electronics industry. CFS produces a list of compliant smelters and refiners. ${ }^{36}$ Only OECD's Due Diligence Guidance and CFS of The Conflict-Free Sourcing Initiative relate to the later stages of the value chain - from smelting upwards. A cooperation of all these certification systems is therefore needed and then it is beneficial for all the partners in the chain and the actors outside.

\footnotetext{
${ }^{35}$ See the Website of ICGLR for further information: https://icglr.org/spip.php?rubrique6.

${ }^{36}$ See the Website of The Conflict-Free Sourcing Initiative: http://www.conflictfreesmelter.org/
} 
It is obvious that the transparency issue is of greatest importance for development and peace in the Great Lakes area, and that many approaches are experimented with and are relevant for some specific actors. The task is complicated, and verification poses numerous technical, scientific and political problems. Anyway, the multitude of concurring systems (see DIHK/DERA October 2010 ) is a handicap for establishing clean supply chains ${ }^{37}$. Ultimately, there are arguments for a broader concept of conflict minerals as laid down in OECD's Due Diligence Guidance for Responsible Supply Chains of Minerals from ConflictAffected and High-Risk Areas (see OECD 2013) and as brought out in the experiences with outright UN Sanctions which also refer to OECD frameworks ${ }^{38}$. The OECD Guidance receives increasing support from the US, the UNSC, and from institutions in Africa like the ICGLR. Recent studies on the role of UN sanctions on natural resources show that it is an indispensable instrument for peace and development, although only scarcely used (see Carisch/Rickard-Martin 2013). However, a new problem has emerged with regard of the global reach of OECD's due diligence guidance: the increasing role of actors from the South (China, India, Brazil, Indonesia, etc.) means that truly global norms have to be established under the guidance of the UN.

As peace and development depend today on such verification and identification systems, the effort is paying off. However, John Maynard Keynes would say that more is needed: stable, simple, effective and binding provisions at the global level and then relating the levels down to the regions and the nationstates. He had conceived ITO/ICU as organizations for global peace and development, and for a global economic and social policy, and all the systems developed now towards more transparency and better governance cannot be a substitute for a globally binding agreement, including such key sectors and policy areas as raw materials, foreign investments, restrictive business practices, employment and social standards, etc.

\footnotetext{
${ }^{37}$ See further information on transparency of supply chains and the various certification and identification systems at: http://www.dihk.de/presse/jahresthema-2012/chart-desmonats/oktober.

${ }^{38}$ See on the OECD Due Diligence Guidance (OECD 2013) and the recent texts the Website: $\mathrm{http}: / /$ www.oecd.org/fr/daf/inv/mne/mining.htm.
} 


\section{Conclusions and Outlook: From the "Transparency Agenda" to the "Structural Reform Agenda" in Regulating Global Resources Sectors}

In this paper, the focus was on the type of global governance relating to international commodity markets and resources sectors. A broader definition of resources beyond oil and gas and minerals was chosen. The question was if the concrete actions surrounding the "transparency agenda", which is currently en vogue, are moving the frameworks for resources sectors step by step towards strong global governance as being implicit in John Maynard Keynes's analyses (on speculation and forward markets as well as on international buffer stocks) and policy prescriptions (especially the ICU/ITO proposals) which he has presented more than 65 years ago.

The paper has looked at five issues. The first issue was on the relevance of the quite recent transparency initiatives being associated with US laws and EU directives, leading to some followers as in Hong Kong. The second issue was on the role of international standards, such as EITI and PWYP. The third issue was on the governance and legislative changes in resource-rich countries aiming to exploit their resources as based on principles such as democracy, equity and sustainability. The fourth issue was on the perspectives of the multi-stakeholder initiatives as instruments to generate public participation concerning resources sectors. The fifth issue was on the certification of "conflict minerals» and «conflict diamonds" along the value chain. All together, these initiatives, standards and procedures are highly ambitious attempts to bring some order to the global resources sectors, and there is commitment from the side of international NGOs and from groups of parliamentarians. However, these initiatives are not based on forms of strict global governance in the sense of simple, stable, effective and binding international commitments by all relevant partners such as requested by John Maynard Keynes in the frame of his ICU/ITO proposals. These five issues of the «Transparency Agenda» lead to actions and proposals to be characterised as partial, voluntary, commodity-specific, country-specific, and non-binding at global levels. There are also contradictions between initiatives, proposals, and also between the amendments to laws (USA) and directives (EU). As well these actions and proposals imply high transaction costs as many actors have to be involved to get minimum consensus and action. Too many actors with different agendas and philosophies are involved, too many gaps in proposed regulations and surveillance mechanisms are observable, and too many problems are left open and are not integrated and compromised. So, all these efforts are leading to weak forms of global governance in respect of resources sectors. Because of the 
very limited impact of the «transparency agenda» on the global resources sectors, global action beyond of it is needed. It is necessary to look at the «Structural Reform Agenda» by addressing the most important issues leading to stable, simple, effective and binding forms of global governance for the resources sectors.

Further five issues are of relevance beside of the five issues emanating from the «Transparency Agenda». The «Structural Reform Agenda» covers also five issues:

The first issue is on the governance of the transnational corporations, the sovereign wealth funds and the government-to-government agreements on commodities and resources. Most relevant in this context are aspects of competition, access, investment and employment, sustainability, transparency and control, and how to come to rules and regulations at the global level (see on the transnational extractive companies UNCTAD 2007, and for the sovereign wealth funds Bernstein/Lerner 2013). So far the transnational resources companies are not really constrained by any coherent global (or regional) control mechanism. Access to resources, investment and labour conditions, competition between big companies and smaller ones, financial flows between companies and governments, monopolized knowledge on reserves and resources, and many sustainability aspects of their activities are not regulated. There is no obligatory check for the 10 biggest oil and gas companies, the 10 biggest mining companies, and the 10 biggest food and agriculture companies, so as to get publicly informed about their huge political, economic and social roles. The impact of these 30 companies is so great that global public policies are needed to set norms and regulations. The same problem is with sovereign wealth funds (SWFs) as they are quite active as finance and investment institutions in the global resources markets and in the global financial system. A Forum on the SWFs exists in the form of a voluntary stakeholder initiative and it is loosely connected to the IMF and other financial actors, but binding rules on their revenue, finance and investment strategies are missing. The level of transparency as practised from the side of the SWFs is minimal, and therefore specific rules and regulations to constrain their behaviour are needed. The bilateral government-to-government treaties on resources exploitation, production and trade (and also those coordinating forums between USA and EU) need also close scrutiny. They may affect in various ways WTO provisions concerning the access to resources in a multilaterals trade framework. Public agencies and rules to control these actors are missing at global levels. Governments are increasingly active in their roles as owners of transnational resources corporations, as owners of SWFs and as partners to bilateral agreements.

The second issue is on the interdependent role of states and markets in regulating international commodity markets. The question is about state failures and market failures in international commodity markets. Both types of failures exist and are not easy to disentangle. Policies of governments towards these markets are not coherent and a great number of different state interventions are used 
to influence these markets. The markets itself are far from competitive conditions, with powerful corporations determining the rules of the game, and knowledge and information asymmetries between contractors (firms as licensees and governments as licensors) abound. Also, cyclical market conditions are prevalent so that producers of the raw materials and beneficiaries from revenues face difficult decisions as investors. Using the lessons from the Political Economy of International Raw Materials Markets for timing and sequencing of reforms is a great task for policy makers. Different types of political economy factors shape the political economy: subsidies paly a great role in all resources sectors; geo-economic aspects of resource extraction are important; institutional deficits lead to suboptimal extraction; and oligopolistic structures affect the outcome of decisions on these markets (see Bleischwitz 2009). And, stocks are in some periods and for some commodities rather small, and storage may be used for speculation and generating benefits from delayed transactions on orders as there are no public stocks organised at global levels. So far there is neither a global agreement on subsidies nor on other political economy factors (to share risks, to overcome the oligopolistic structure, and to react to the high cyclicality of investments), and global public action along the programme of $\mathrm{J}$. M. Keynes is non-existent. This is true for agriculture and food, for mining, and for oil and gas exploration. Markets are highly impacted by subsidies and by government interventions, but global action is scarce. More and more private and public actors merged in spheres of interest. All attempts have failed to bring order to these markets, and the Doha negotiations are only one element of a highly unsatisfactory story. As resources are distributed unevenly between regions and continents, the access to information about reserves and resources and the global logistics of the extraction industry are important. There are myths about abundance (mainly with regard to minerals and also land related to Africa), although these myths (see Simons 2012) may be fuelled largely by the motive to get access to resources at very low costs (in terms of environmental legislation, social and safety standards for the workers, access to licenses for exploration and extraction, etc.). There is tremendous need for global public information about the abundance of reserves and resources, and also for global policy frameworks to encounter the political economy factors of these resources sectors.

The third issue is on focussing regulations and reforms on global agriculture and food production under land, water, and energy stresses. It is necessary to look at the perspectives of Sustainable Agriculture and Food Production in the context of Climate Change Mitigation and Adaptation (especially in Africa because of the expected great number of people under risk of food insecurity and because of the probability that the continent will bear quite heavily the burden of the negative effects of climate change). Recent scenarios show that feeding the 9 to 10 billion people projected for the year 2050 can be done in quite different forms - in unsustainable forms associated with a further "conventional intensification" of agricultural production and in more sustainable forms of agricultural production based on an «ecological intensification» (see INRA/CIRAD 2009, Pail- 
lard et al. 2011, and IFPRI 2013, Chapter 8). The more sustainable forms of feeding 9 to 10 billion people will request strict/strong global governance on food security, involving also limits set to the calories that are consumed in OECD countries and in the fast growing emerging economies. Such a new global order to aim at food security must be based on strict global governance in the sense of requesting from all major actors (national governments, regional and international organisations, transnational food and agriculture corporations, public international agricultural research organizations) new ecological, social, economic, political, trade and technology orientations. Strong global governance is necessary to allow simultaneously for poverty reduction, food security, sustainable agricultural production and climate change adaptation. The implications of these alternative scenarios for Africa and their many people being at «risk of food insecurity» are diverging considerably. In case of "conventional intensification» of agricultural production the impacts on ecology, land, water and energy use, deforestation and climate change will deviate severely from the impacts under "ecological intensification». Beside of this basic decision to be taken there are further challenges for Africa depending on various downside risk factors (higher population projections, more unfavourable climate change projections, much higher energy price projections). A global organization is therefore needed to bring all these aspects coherently and under a consistent framework together - such as the proposed UN Food Security Organization (UNFSO). Such an organization can work for sustainable global food production while reducing effectively food insecurity. Areas under land, water and energy stresses and areas threatened most by climate change, as some African regions, can benefit from such a concerted action of the UNFSO. At the moment, too many international organizations do some work on agriculture, trade, investment and sustainable development, but without a clear focus on food security. A Global Governance of Food Security is especially important for the stability of production, trade and investment in agriculture and food sectors.

The fourth issue is on the paths towards a Comprehensive Global Resources Policy and a Global Resources Management Regime. There is a serious lack of comprehensive resources policies and management regimes at local, sub-national, national, regional and global levels. Comprehensive policies at the national level will support comprehensive policies and policy frameworks at the regional and global levels, and will so contribute to crisis prevention and conflict prevention. National «best practice» could then be used to improve policy frameworks in other countries and at regional and global levels. Such an approach will also help to avoid "Resource Curse» and "Dutch Disease» effects as successful national strategies are promoted worldwide. A Global Resource Management Regime is feasible and has various components: national resource funds are needed to make the economy more independent from price and revenue volatility, to invest into "equity» measures and to save for future generations; transparency has to be increased along the resource value chains and all revenue uses; appropriate sustainability standards and certification procedures along 
the resource value chains are needed so as to improve sustainability levels of production; development aid should focus on «resources for development» programmes so that the management of resource revenues becomes an important part of the global aid agenda (what is not at all the case now); increasing material efficiency and resource productivity is an issue for developed, emerging and less developed countries so that technology transfers contribute to progress in the manufacturing industry worldwide; and measures are needed to limit resource consumption to a sustainable level what is needed for agricultural production, but also for mining, oil and gas production (see on the agenda Bleischwitz/Bringezu 2007). A Global Resources Management Regime (GRMR) could coordinate national and regional policies towards globally coordinated and comprehensive resource policies. Comprehensive policies have yet to be conceived in most of the resource-rich countries and - with regard of material efficiency and resource productivity - also in developed countries. Not many national resource funds are working in developing countries; the application of international transparency and sustainability standards is weak at national and local levels, and the coordination of resource production sectors with agriculture and manufacturing sectors is weak so that the production and the use of resources do not contribute to structural transformation what is a great problem in Africa today (AfDB et al., 2013). Comprehensive resource policies are also needed at regional levels as otherwise national export restrictions with regard of food and other forms of access interruptions will increase price volatility and food insecurity (what was observed in both periods of price increases 2007/08 and 2011/2012 in Africa). It is astonishing that international aid was so weak in concrete action and specific advice with regard of resource sectors. Proposals for Global Resources Management Regimes (GRMRs) are found in international proposals and resolutions but important is translation into action (see Chatham House 2012 and Bleischwitz/ Bringezu 2007, pp. 9-11).

The fifth issue is on Establishing Global Rules on Commodity Markets and Resource Sectors and on Introducing New Multilateral Trade, Finance and Investment Rules which are complementary. WTO and formerly the GATT were conceived as institutions to reduce quantitative restrictions and duties on the import side. Much less was done to look at the export side what was an aspect in the ITO Charter. Recent export restrictions of food products and rare metals highlight the importance of the issue, although there are other many aspects concerning the export side (export of goods and inputs with dangerous environmental effects, unsafe products, products from conflict areas, products produced by child labour and forced labour, etc.). There are also other aspects (export subsidies, export incentives, implicit export restrictions by large and transnational corporations). It is important to look at rules and regulations of the WTO system to bring in the commodity sector and the resources sectors including land, water, and energy, and to design related trading rules. Also, the WTO system is important in the context of food security as trading rules (for imports and exports) should allow it to give incentives for an ecological intensification of global food 
production in order to preserve nature and mitigate climate change. This may also mean to give preferences for regional trade and regional value chains. There is a need to reform the WTO system accordingly so that an equitable access to resources which are produced under sustainable conditions is supported by a high level of transparency and certification of such trade flows in binding regional and global trade rules. Appropriate action needs to be undertaken, although the experiences of the Doha Round show that awareness for deeper reforms of the WTO system is still lacking. Too many issues are left out from the WTO system with regard of commodities and resources (see Stürmer 2008; Ruta/Venables2012; Bleischwitz 2007; Bleischwitz/Bringezu 2007): Export duties of resource-rich countries can be used to favour certain countries against political concessions; mining investments are not at all regulated in the WTO framework, so that there is no international transparency on the access to resources, the allocation of exploration and extraction licenses, etc.; there is no link of raw materials policy with competition laws in WTO member states so as to prevent the further concentration of already powerful raw materials companies; there are various exceptions in the WTO system to the ban on export restrictions of food and raw materials, such as in cases of critical shortages of important products, but also to protect nature and environment, and in cases of intergovernmental raw materials agreements, and the non-discriminatory handling of such export bans is not guaranteed (as one could see in recent times of large food price increases). Even low import tariffs on raw materials in importing countries can have a high protective effect because of the low processing stage in the exporting countries, and there are no binding obligations on export duties (see Stürmer 2008).

Despite of all this, no WTO agreement on international competitive bidding for exploration and extraction licenses is in sight, and nothing came out so far from proposals for a comprehensive WTO treaty on export tariffs (which could be linked to the dispute settlement mechanism of WTO), so that widespread raw materials protectionism could be prevented and punished (Stürmer 2008, p. 135). All these new treaties could help to reduce the role of bilateral raw materials agreements which have acted more and more as instruments for the race on scarce raw materials. Agreements on mining and other resources investments are needed, to create a climate of transparency but also to improve on the long term contracts on resources which have serious weaknesses. Most important, requested are a «transparent and non-discriminatory allocation of extraction licenses and a commitment to environmental and social standards for foreign investments in mining» (Stürmer 2008, p. 136). More than this, not only the traditional policy agenda matters with instruments like export taxes, price controls, production quotas, domestic producer and consumer taxes, but also the market failures with regard of the long run contracts for exploration and development of natural resources (see Ruta/Venables 2012). Resource contracts are different from other foreign direct investment (FDI) and so a multilateral surveillance role of WTO is needed. Access to raw materials is important for industrialization and 
development, and J. M. Keynes has always argued that access interruptions can lead to war and violent conflict. Auction-type open allocations of extraction licenses are needed. New WTO regulations are also needed because of the new actors in emerging countries which may not be bound by OECD Due Diligence rules. And the WTO can play such a role by using the instrument of waivers. The Kimberley Process (KP) WTO waiver is an example that multilateral agreements on raw materials are possible, and that voluntary agreements as on "conflict diamonds" can become part of binding WTO rules (Ruta/Venables 2012, p. 28). The WTO role in enforcing resource contracts is highly important (Ruta/Venables 2012, p.27), as such contracts decide about future growth potentials and global competition should be based on knowledge in manufacturing firms and not on the power of transnational resource companies. WTO rules also matter in order to allow industrial policies in developing countries. As resource-rich countries need to diversify their production and export activity they should be allowed to use firstbest instruments to support industrial development (like specific subsidies) and not second-best or third-best instruments (like export taxes and export bans). Industrial policy should not conflict with the Subsidies and Countervailing Measures (SCM) Agreement of WTO. The use of modern-type industrial policies should be facilitated by WTO measures so that restrictive export sector measures are avoided. The change from surplus to scarcity in global raw materials markets has changed completely since 2007/2008 the situation, and the need for international and multilateral trading and transparency rules has tremendously increased.

Not only export policies, raw materials contracts and raw materials investments are left out from the WTO agenda; also transparency of raw materials markets is so far not part of the multilateral agenda. It would be necessary to install transparency on subsidies, shareholding, exploration and delivery contracts, the properties of traded materials, the environmental impacts of materials and inputs. An international panel on the sustainable use of natural resources was recommended and could be linked with WTO surveillance activities and rule-setting agendas (see Bleischwitz 2007, p. 77). Public information systems on raw materials markets would be needed at international level, to document on production, storage, trade, but also on export policies of resource-rich countries, on bilateral agreements with importing countries, and on resource contracts as well as on the behaviour of transnational resource corporations. WTO provisions do not contain so far rules allowing the institution to sanction unsustainable resource use by implementing trade restrictions (Bleischwitz/Bringezu 2007, p. 11). An international panel on sustainable development could give advice to WTO committees. A binding multilateral agreement to promote sustainability principles in resource extraction, processing and trade as well as providing technological assistance to less developed resource-rich countries would be an important improvement in global resource politics (Bleischwitz 2007, p. 77). In fact, these were already the ideas by $\mathrm{J}$. M. Keynes on the regulation of commodity markets more than 65 years ago. 
Also with regard of resource-related global finance new international rules are needed, and a stronger role of IMF and World Bank is requested. As discussed above, various voluntary initiatives are in place. However, these initiatives are not really linked to IMF and World Bank policies. The increasing role of resource-related finance from emerging countries adds to the importance of such global regulations. The interaction of food, energy, land and other resource markets is a factor to be considered as highly important in this context. The transparency initiative of the Dodd-Frank Act to fight corruption with regard of raw materials has brought the US laws on stock exchanges to the centre of interest; other countries responded. Also other financial sector issues are at stake and reforms are demanded. There is now an intensive debate about the role of speculation on food and land resources, and international rules for stock exchanges, securities and exchange commissions and for other financial supervisory agencies are discussed. Links with the IMF are needed, but so far not too much has happened. A case in point is the discussion about «index speculation» on food. Proposals to impact globally on the index speculation with food and other resources were in recent years regularly made. Restrictions on the use of index-oriented financial products based on food could play a certain role if there is an internationally coordinated approach and if selective demand-side and supply-side measures on food markets are based on sustainable development strategies. Crisis management with regard of of global food security also requests that short-term measures such as restrictions on index speculation are backed by medium to longterm programmes (see Bass 2012). None of the proposals made by the UN after the food price crisis of 2007/2008 for dealing with speculation on food was realised (the report by De Schutter: 2010 with many proposals for action is a good example). Even a Comprehensive Framework for Action (CFA) to secure the «human right to food» was presented in this context but without any internationally binding commitment. Curiously enough, the De Schutter Report concludes that many index speculators are not interested and knowledgeable in commodities and so they should be excluded from trading in index funds (De Schutter, 2010 , p. 8). This view ignores the fact that large institutional investors (international banks, global insurance companies, and large financial funds and companies) are doing business with such financial products and not the single uninformed trader. It was a welcome start from the «human right to food» people in the UN and not from the core institutions such as IMF and World Bank and the major stock exchanges in the world. A complete reform of global financial systems is requested by UN and NGO circles to impact on the resources markets: Index speculation and over the counter derivatives are an issue in the discussion about new rules for financial products related to resource markets, but new rules are as well important for resource sector financing - with regard of the access to resource concessions and licenses and with regard of resource sector investments by transnational corporation and sovereign wealth funds in resource-rich countries. Some elements of the ITO/ICU agenda are still relevant in this context, and many observers argue that stricter rules for the regulation of the commodity sectors can be incorporated into the frameworks of WTO, IMF, World Bank, ILO, 
and even of UNEP and UNDP. So the frameworks for the regulation of resource markets and sectors can be improved even on the basis of the available global governance machinery.

The "Structural Reform Agenda» involves stricter rules of global governance of resource sectors. Ten issues were discussed, in the form of guidelines for action at the global level, five issues for the "Transparency Agenda» and five issues for the "Structural Reform Agenda». Global governance of the resources sectors requires - in the sense of the analyses, proposals and views as presented by J. M. Keynes many decades ago - that globally binding rules are established so as to ensure stable, simple, consensual and efficient frameworks. However, the "Transparency Agenda" may be viewed as a first step to raise awareness about the issues and problems. It becomes clear that internationally coordinated actions towards deeper global governance of resource sectors are requested for fair global competition, and for peace and development. The current discussion also has the advantage to show how important a global comprehensive and sustainable resources policy is, and that a broader look at resources is needed beyond oil and gas and mining, including also land, food and agriculture, livestock, water, fisheries, energy and power resources.

\section{References}

1. Acosta, Andres Mejia, 2010, Review of Impact and Effectiveness of Transparency and Accountability Initiatives: Annex 4, Natural Resource Governance, Prepared for the Transparency and Accountability Initiative Workshop, October 14 - 15, 2010, Brighton, Sussex, IDS/Institute of Development Studies, October 2010, 18 pages; Web Access: http://www.ids.ac.uk/files/dmfile/ IETAAnnex4NatResGovMejiaAcostaFinal28Oct2010.pdf.

2. ADB/African Development Bank/IACC/International Anti-Corruption Conference, 2010, Fuelling Transparency and Accountability in the Natural Resources and Energy Markets, by Alexandra Gillies, $14^{\text {Th }}$ International AntiCorruption Conference, 10 - 13 November 2010, Bangkok, Thailand, 11 pages; Web Access: http://14iacc.org/wp-content/uploads/ AlexandraGillesNaturalResourcesIACC.pdf.

3. African Development Bank (AfDB)/Development Centre Of The Organization For Economic Co-operation And Development (OECD)/United Nations Development Programme (UNDP)/United Nations Economic Commission For Africa (UNECA), 2013, African Economic Outlook 2013, Special Theme: Structural Transformation and Natural Resources, Paris: OECD Publishing 2012, pages: 357; Web Access: http://www.africaneconomicoutlook.org/en/ 
4. African Development Bank (AfDB)/Development Centre Of The Organization For Economic Co-operation And Development (OECD)/United Nations Development Programme (UNDP)/United Nations Economic Commission For Africa (UNECA), 2012, African Economic Outlook 2012, Special Theme: Promoting Youth Employment, Paris: OECD Publishing, 2012, 291 pages; Web Access (with detailed Country Notes): http://www.africaneconomicoutlook.org/en/

5. Argandona, Antonio, 2006, The United Nations Convention Against Corruption And Its Impact On International Companies, Working Paper, WP no. 656, October 2006, IESE Business School, University of Navarra, "la Caixa» Chair of Corporate Responsibility and Corporate Governance, 22 pages; Web Access: http://www.iese.edu/research/pdfs/DI-0656-E.pdf.

6. Badal, Lionel, 2012, Managing Risks in the Extractive Industries, African Arguments, October 25, 2012, Web Access: http://africanarguments.org/2012/10/ 25/managing-risks-in-the-extractive-industries-\%E2\%80\%93-by-lionel-badal/

7. Bass, Hans-Heinrich, 2012, Welternährung in der Krise, GIGA Focus Global, Nummer 5, 2012, Hamburg: GIGA, 8 pages.

8. Bernstein, Shai/Josh Lerner/Antoinette Schoar, 2013, The Investment Strategies of Sovereign Wealth Funds, pp. 219-238, in: Journal of Economic Perspectives, Volume 27, Number 2, Spring 2013.

9. BGR/ Bundesanstalt für Geowissenschaften und Rohstoffe, 2010, Certified Trading Chains in Mineral Production, Project Outline and Status, Hannover: BGR May 2010, 9 pages; Web Access: http://www.bgr.bund.de/EN/Themen/ Min_rohstoffe/Downloads/CTC-update-Mai2010.pdf?_blob=publicationFile\&v=1.

10. Bleischwitz, Raimund, 2009, International Raw Materials Markets: Rising Prices and Growing Conflict Potential, pp. 65 - 78, in: GLOBAL TRENDS 2007 - VULNERABILITY AND HUMAN SECURITY IN THE 21ST CENTURY, Tobias Debiel et al., eds., Foundation for Development and Peace (SEF): Bonn, 2006; Web Access: http://www.sef-bonn.org/fileadmin/Die_SEF/ Publikationen/Globale_Trends/gt_2007_raw-materials_en.pdf.

11. Bleischwitz, Raimund/Stefan Bringezu, 2007, Global Resource Management, Conflict Potential and Characteristics of a Global Governance Regime, Policy Paper 27, Stiftung Entwicklung und Frieden/Development And Peace Foundation, Bonn: SEF 2007, 12 pages; Web Access: http://base.socioeco.org/ docs/sef-pp-27-end-en.pdf.

12. BGR/Bundesanstalt für Geowissenschaften und Rohstoffe, 2013, The Analytical Fingerprint (AFP), Method and Application, Process Manual, Version 1.3, Hannover/Bujumbura: BGR January 2013, 47 pages; Web Access: http://www.bgr.bund.de/EN/Themen/Min_rohstoffe/CTC/Downloads/AFP_Ma nual.pdf?_blob=publicationFile \& $v=6$.

13. Bryan, Shari/Barrie Hofmann, Eds., 2007, Transparency and Accountability In Africa's Extractive Industries: The Role Of The Legislature, Washington 
D. C.: National Democratic Institute for International Affairs 2007, 107 pages; Web Access: http://www.ndi.org/files/2191_extractive_080807.pdf.

14. Carabelli, Anna M./Mario A. Cedrini, 2012, Some Foreseeable Disasters Of The Global Economy: The high Cost Of Neglecting Keynes's Approach, Department of Economics, «S. Cognetti de Martiis», Centro di Studi sulla Storia e I Metodi dell' Economia Politica «Claudio Napoleoni» (CESMEP), Working Paper Series, Working Paper No. 01/2012, Universita di Torino, 24 pages; Web Access: http://www.cesmep.unito.it/WP/2012/1_WP_Cesmep.pdf.

15. Carisch, Enrico/Loraine Rickard-Martin, 2013, Sanctions and the Effort to Globalize Natural Resources Governance, International Policy Analysis, FES New York, January 2013, Friedrich-Ebert-Stiftung, 14 pages; Web Access: http://library.fes.de/pdf-files/iez/global/09578.pdf.

16. Cavalli, Nicolo/Carlo Cristiano, 2012, Keynes's speculation in the London tin market: 1921-1930, pp. 57ff, in: Marcuzzo, M. C., Ed., op. cit.; Web Access: http://mpra.ub.uni-muenchen.de/44131/1/MPRA_paper_44131.pdf.

17. CFS (Committee on World Food Security)/FAO (Food and Agriculture Organization), 2012, Voluntary Guidelines On The Responsible Governance of Tenure Of Land, Fisheries And Forests In The Context Of National Food Security, Rome: Food and Agriculture Organization Of The United Nations 2012, 48 pages; Web Access: http://www.fao.org/docrep/016/i2801e/i2801e.pdf.

18. Chatham House, 2012, Resources Futures, A Chatham House Report by Bernice Lee/Felix Preston/Jaakko Kooroshy/Rob Bailey and Glada Lahn, Chatham House, London: Royal Institute of International Affairs, December 2012, 234 pages; Web Access: http://www.chathamhouse.org/sites/default/ files/public/Research/Energy,\%20Environment\%20and\%20Development/121 2r_resourcesfutures.pdf.

19. Cifarelli, Giulio/Paolo Paesani, 2012, A new test of the theory of storage comparing historical and contemporary data, pp. 151ff, in: Marcuzzo, M. C., Ed., op. cit.; Web Access: http://mpra.ub.uni-muenchen.de/44131/1/ MPRA_paper_44131.pdf.

20. Cristiano, Carlo/Nerio Naldi, 2012, Keynes's activity on the cotton market and the theory of the 'normal backwardation': 1921-1929, pp. 25ff, in: Marcuzzo, M. C., Ed., op. cit.; Web Access: http://mpra.ub.uni-muenchen.de/44131/1/ MPRA_paper_44131.pdf.

21. Cristiano, Carlo/Paolo Paesani, 2012, Kaldor and the relationship between 'normal backwardation' and the theory of storage, pp. 129ff, in: Marcuzzo, M. C., Ed., op. cit.; Web Access: http://mpra.ub.uni-muenchen.de/44131/1/ MPRA_paper_44131.pdf.

22. Darby, Sefton, 2010, Natural resource governance, New frontiers in transparency and accountability, London: Transparency \& Accountability Initiative, 
2010, 69 pages; Web Access: http://www.transparency-initiative.org/wpcontent/uploads/2011/05/natural_resources_final1.pdf.

23. De Schutter, Olivier, 2010, Food Commodities Speculation and Food Price Crises, Regulation to reduce the risks of price volatility, Briefing Note 02 September 2010, United Nations Human Rights Council/UN Special Rapporteur on The Right To Food; Web Access: http://www.srfood.org/images/ stories/pdf/otherdocuments/20102309_briefing_note_02_en_ok.pdf.

24. DIHK/Deutsche Industrie- und Handelskammer/DERA/Deutsche Rohstoffagentur, 2012, DERA-Chart Des Monats, Zertifizierung mineralischer Rohstoffe in der Rohstofflieferkette, DIHK/DERA Oktober 2012; Web Access: http://www.heilbronn.ihk.de/ihkhnenergie/dachmarken.aspx?tablD=0\&msgID=1107.

25. Drache, Daniel, 2000, «The Short but Significant Life of the International Trade Organization: Lessons for Our Time», CSGR Working Paper No. 62/00, November 2000, Centre For The Study Of Globalisation And Regionalisation, University Of Warwick, Coventry, UK, 43 Pages; Web Access: http://dspace.cigilibrary.org/jspui/bitstream/123456789/9491/1/The\%20Short $\% 20$ But $\% 20$ Significant $\% 20$ Life $\% 20$ of\%20the $\% 20$ International\%20Trade $\% 20$ Organization\%20\%20Lessons\%20For\%20Our\%20Time.pdf?1.

26. Ebertz, Utz/Marie Müller, 2013, Legacy of a resource-fueled war: The role of generals in Angola's mining sector, BICC Focus 12, June 2013, Bonn: BICC, 17 pages; Web Access: http://www.bicc.de/uploads/tx_bicctools/ BICC_FOCUS_12.pdf.

27. Fantacci, Luca, 2012, Keynes's commodity and currency plans for the postwar world, in: Marcuzzo, Ed., op. cit.; Web Access: http://mpra.ub.unimuenchen.de/44131/1/MPRA_paper_44131.pdf.

28. Foresti, Tiziana/Eleonora Sanfilippo, 2012, An analysis of Keynes's investments in the wheat futures markets: 1925-1935, pp. 79ff, in: Marcuzzo, Ed., op. cit.; Web Access: http://mpra.ub.uni-muenchen.de/44131/1/ MPRA_paper_44131.pdf.

29. George, Susan, 2007, Alternative Finances, The World Trade Organisation We Could Have Had, in: Le Monde Diplomatique, English Edition, 2007/01/03; Web Access: http://mondediplo.com/2007/01/03economy.

30. Global Witness, 2012, Financing A Parallel Government? The involvement of the secret police and military in Zimbabwe's diamond, cotton and property sectors, June 2012, Global Witness, 33 pages; Web Access: http://www.globalwitness.org/sites/default/files/library/Financing_a_parallel_g overnment_Zimbabwe.pdf.

31. Horsefield, J. Keith, Ed., 1969, The International Monetary Fund 1945-1965, Twenty Years of International Monetary Cooperation, Volume III: Documents, Washington, D. C.: International Monetary Fund 1969, 42 pages; Web Access: http://www.imsreform.org/reserve/pdf/keynesplan.pdf. 
32. ICGLR (International Conference on the Great Lakes Region) News Bulletin July 2013, p. 7 on a regional certificate on the origin of minerals in DRC; Web Access: https://icglr.org/IMG/pdf/July_Bulletin_ENG2.pdf.

33. IFPRI/International Food Policy Research Institute, 2013, Global Food Policy Report 2012, Washington D. C.: IFPRI 2013, Chapter 8; Web Access: http://www.ifpri.org/sites/default/files/publications/gfpr2012.pdf.

34. INRA/CIRAD, 2009, Agrimonde, Scenarios and Challenges for Feeding the World in 2050, Summary Report, Paris: INRA/CIRAD, December 2009; Web Access: PDF CIRAD, http://www.cirad.fr.

35. IWG (International Working Group Of Sovereign Wealth Funds), 2008, Sovereign Wealth Funds, Generally Accepted Principles and Practices - «Santiago Principles», Washington D. C.: October 2008, 59 pages; Web Access: http://www.iwg-swf.org/pubs/eng/santiagoprinciples.pdf.

36. Kufuor (Former President of Ghana) Speech 2013, Web Access: http://www.acme-ug.org/news/item/489-former-ghanaian-president-kufuorspeaks-on-oil-governance-at-makerere.

37. Lauster, Gitta/Stormy-Annika Mildner/Wiebke Wodni, 2010, Transparenz im Rohstoffhandel, US-Finanzgesetz soll Handel mit Konfliktressourcen eindämmen, SWP-Aktuell 76, November 2010, Stiftung Wissenschaft und Politik, Deutsches Institut für Internationale Politik und Sicherheit, Berlin: 2010, ISSN 1611-6364, 4 Seiten; Web Access: http://www.swp-berlin.org/ fileadmin/contents/products/aktuell/2010A76_lag_mdn_wodni_ks.pdf.

38. Marcuzzo, M. C., Ed., 2012, Speculation and regulation in commodity markets: The Keynesian approach in theory and practice, Dipartimento di Scienze Statistiche, Rapporto Tecnico N. 21, 2012, ISSN- 2279-7911, 286 pages; Web Access: http://mpra.ub.uni-muenchen.de/44131/1/MPRA_ paper_44131.pdf.

39. Marcuzzo, M. C., 2012, From speculation to regulation: Keynes and primary commodity markets, pp.3ff, in: Marcuzzo, M. C., Ed., op. cit.; Web Access: http://mpra.ub.uni-muenchen.de/44131/1/MPRA_paper_44131.pdf.

40. Mildner, Stormy-Annika/Florian Wassenberg, 2012, Rohstoffreichtum darf nicht länger arm machen, Warum die EU-Mitgliedstaaten strengere Regeln für die Offenlegung von Zahlungen im Rohstoffsektor unterstützen sollten, SWP-Aktuell 43, Juli 2012, Berlin: SWP/Stiftung Wissenschaft und Politik/Deutsches Institut für Internationale Politik und Sicherheit, ISSN 16116364, 8 Seiten; Web Access: http://www.swp-berlin.org/fileadmin/contents/ products/aktuell/2012A43_mdn_wsb.pdf.

41. NRC (Natural Resource Charter), November 2010, 24 pages; Web Access: http://naturalresourcecharter.org/sites/defaultfiles/nrc_brochure_Nov2010_Eng.pdf. 
42. OECD, 2013, OECD Due Diligence Guidance for Responsible Supply Chains of Minerals from Conflict-Affected and High Risk Areas, Second Edition, Paris: OECD Publishing, 122 pages; Web Access: http://www.oecd.org/ daf/inv/mne/GuidanceEdition2.pdf.

43. ONE/Transparency International/Misereor/Brot für die Welt, 2013, Hintergrundinformation: EU Regulierung zur Steuertransparenz von Erdöl-, Erdgas-, Bergbau- und Holzeinschlagsunternehmen, mit Web-Zugang zu den Kompromisstexten, Web Access: http://www.transparency.de/fileadmin/pdfs/ Themen/Internationales/Hintergrund_EU_Buchhaltungs-TransparenzrichtlinieJuni_2013.pdf.

44. Paillard, S./S.Treyer/B. Dorin, coord., 2011, Agrimonde, Scenarios and Challenges for Feeding the World in 2050, Editions Quae, Paris 2011.

45. PWYP (Publish What You Pay), The Cardin-Lugar Amendment (Dodd-Frank 1504), Web Access: www.publishwhatyoupay.org/about/stock-lisitngs/cardinlugar-amendment-dodd-frank-1504.

46. Rosselli, Annalisa, 2012, Richard Kahn and the stabilization of commodity prices, pp. 207ff, in: Marcuzzo, M. C., Ed., op. cit.; Web Access: http://mpra.ub.uni-muenchen.de/44131/1/MPRA_paper_44131.pdf.

47. Ruta, Michele/Anthony J. Venables, 2012, International Trade in Natural Resources: practice and policy, World Trade Organization (WTO), Economic Research and Statistics Division, Staff Working Paper ERSD-2012-07, Date: March 2012, 35 pages; Web Access: http://www.wto.org/english/ res_e/reser_e/ersd201207_e.pdf.

48. Simons, Bright, 2012, Africa's Fabulous Mineral Wealth that isn't ALL there, in: African Arguments, September 18, 2012; Web Access: http://africanarguments.org/2012/09/18/africa\%E2\%80\%99s-fabulousmineral-wealth-that-isnt-all-there-\%E2\%80\%93-by-bright-simons/

49. Skidelski, Robert, 2005, Keynes, Globalisation and the Bretton Woods Institutions in the Light of Changing Ideas about Markets, pp. 15-30, in: World Economics, Vol. 6, No. 1, January-March 2005, 16 pages; Web Access: http://www.oxonia.org/WE\%20articles/WE_skidelsky.pdf.

50. Stürmer, Martin, 2008, The International Raw Materials Boom, A Challenge for Multilateral Trade Policy, pp. 126 - 139, in: Internationale Politik und Gesellschaft (IPG), 2, 2008, 14 pages; Web Access: http://library.fes.de/pdffiles/ipg/ipg-2008-2/09_a_stuermer_gb.pdf.

51. The Guardian, Datablog, Claire Provost, Facts are sacred, 2012, International land deals: who is investing and where - get the data, Web Access: http://www.theguardian.com/global-development/datablog/2012/apr.

52. TNI/Transnational Institute, 2012, The Global Water Grab - A Primer, by Sylvia Kay and Jenny Franco, Amsterdam: TNI March 2012, 24 pages; Web Ac- 
cess: http://www.tni.org/sites/www.tni.org/files/download/ watergrabbingprimeraltcover2.pdf.

53. U4 Brief, 2012, Implementing the illicit financial flows agenda: Perspectives from developing countries, U4 Brief, September 2012, no. 8, Bergen, Norway: CMI (Chr. Michelsen Institute) - U4; Web Access: http://www.u4.no/publications/illicit-financial-flows-and-measures-to-counterthem-an-introduction/

54. UNCTAD/United Nations Conference On Trade And Development, 2007, World Investment Report (WIR) 2007, Transnational Corporations, Extractive Industries and Development, New York and Geneva: United Nations 2007, 323 pages; Web Access: http://unctad.org/en/Docs/wir2007_en.pdf.

55. UNECOSOC/United Nations Economic And Social Council/ECA/Economic Commission For Africa, 2013, The State of Governance in Africa: The Dimension of Illicit Financial Flows as a Governance Challenge, Third Meeting of the Committee on Governance and Popular Participation, Addis Ababa, Ethiopia, 20 and 21 February 2013, Document: E/ECA/CGPP/3/2, 18 February 2013, Original: English; Web Access: http://www.uneca.org/sites/default/ files/uploaded-documents/CGPP/cgpp-3_illicit-financial-flow-english_final.pdf.

56. UNCTE/United Nations Conference On Trade And Employment, 1948, UNCTE held at Havana, Cuba, From November 21, 1947 To March 24, 1948, Final Act And Related Documents, Interim Commission For The International Trade Organization, Lake success, New York, April 1948, 126 pages; Web Access: http://www.wto.org/english/docs_e/legal_e/ havana_e.pdf.

57. UNECOSOC/United Nations Economic And Social Council/ECA/Economic Commission For Africa, 2011, Africa Report on Institutional and Strategic Frameworks for Sustainable Development, Summary for Policy Makers, Seventh Session of the Committee on Food Security and Sustainable Development (CFSSD-7) and the African Regional Preparatory Conference for the United Nations Conference on Sustainable Development (Rio+20), Addis Ababa, Ethiopia, 20-25 October 2011, Document E/ECA/CFSSD/7/10, August 2011, Original: English, 18 pages; Web Access: http://www.uneca.org/ sites/default/files/uploaded-documents/rio20_15-eastern-africa-summary-forpolicy-makers.pdf.

58. UNEGM/United Nations Expert Group Meeting, 2006, UNEGM on Natural Resources and Conflict in Africa: Transforming a Peace Liability into a Peace Asset, Conference Report, 17 - 19 June 2006, Cairo, Egypt, Organized by the Office of the Special Adviser on Africa (OSAA) in cooperation with the Government of Egypt, 72 pages; Web Access: http://www.un.org/africa/ osaa/reports/Natural\%20Resources\%20and\%20Conflict\%20in\%20Africa_\%2 0Cairo\%20Conference\%20ReportwAnnexes\%20Nov\%2017.pdf. 
59. Ussher, Leanne J., 2012, Combining International Monetary Reform with Commodity Buffer Stocks: Keynes, Graham and Kaldor, Draft, December 19, 2012, Economics Department, Queens College, City University of New York, 38 pages; Web Access: http://blog.global-systems-science.eu/wp-content/ uploads/2012/11/ussher_Bancor_19Dec12.pdf.

60. Wohlmuth, Karl, 2012, Towards A Strategic Framework for Economic Cooperation between Sudan and South Sudan, Sudan Economy Research Group (SERG) Discussion Papers Number 40, IWIM/SERG, University of Bremen, Bremen, September 2012, 61 pages; Web Access: http://www.iwim.unibremen.de/Siakeu/Wohlmuth-SERG-40.pdf. 